\title{
CUTTING TOOL STUDY 21-6-9 STAINLESS STEEL
}

\author{
A. P. McManigle
}

\section{@NEGEG ROCKY FLATS \\ Rocky Flats Plant \\ P. O. Box 464 \\ Golden, Colorado 80402-0464}




\section{DISCLAIMER}

This report was prepared as an account of work sponsored by an agency of the United States Government. Neither the United States Government nor any agency Thereof, nor any of their employees, makes any warranty, express or implied, or assumes any legal liability or responsibility for the accuracy, completeness, or usefulness of any information, apparatus, product, or process disclosed, or represents that its use would not infringe privately owned rights. Reference herein to any specific commercial product, process, or service by trade name, trademark, manufacturer, or otherwise does not necessarily constitute or imply its endorsement, recommendation, or favoring by the United States Government or any agency thereof. The views and opinions of authors expressed herein do not necessarily state or reflect those of the United States Government or any agency thereof. 


\section{DISCLAIMER}

Portions of this document may be illegible in electronic image products. Images are produced from the best available original document. 


\section{DISCLAIMER}

This report was prepared as an account of work sponsored by an agency of the United States Government. Neither the United States Government nor any agency thereof, nor any of their employees, makes any warranty, expressed or implied, or assumes any legal liability or responsibility for the accuracy, completeness, or usefulness of any information, apparatus, product, or process disclosed, or represents that its use would not infringe privately owned rights. Reference herein to any specific commercial product, process, or service by trade name, trademark, manufacturer, or otherwise, does not necessarily constitute or imply its endorsement, recommendation, or favoring by the United States Government or any agency thereof. The view and opinions of authors expressed herein do not necessarily state or reflect those of the United States Government or any agency thereof.

This report has been reproduced directly from the best available copy.

Available to DOE and DOE contractors from the Office of Scientific and Technical Intormation, P. O. Box 62, Oak Ridge, TN 37831; prices available from (615) $576-8401$, FTS 626-8401.

Available to the public from the National Technical Information Service, U.S. Department of Commerce, 5285 Port Royal Rd., Springfield, VA 22161. 
RFP-4552

July 29, 1992
RFP-4552

UC-706 ENGINEERING, EQUIPMENT AND INSTRUMENTS DOE/OSTI-4500 (Rev. 75)

RFP- -4552

DE93 001293

\title{
CUTTING TOOL STUDY
}

\section{1-6-9 STAINLESS STEEL}

\author{
A. P. McManigle
}

SUBJECT DESCRIPTORS

Machining

Turning

21-6-9 Stainless Steel

\author{
EG\&G ROCKY FLATS, INC. \\ ROCKY FLATS PLANT \\ P. O. BOX 464 \\ GOLDEN, COLORADO 80402-0464
}

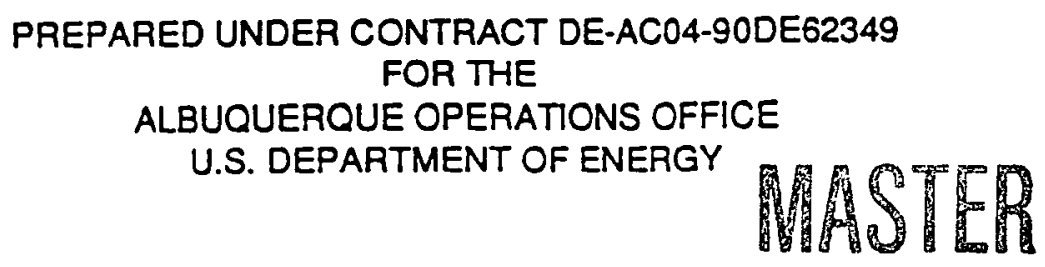

ALBUQUERQUE OPERATIONS OFFICE

U.S. DEPARTMENT OF ENERGY 
RFP-4552 


\section{CONTENTS}

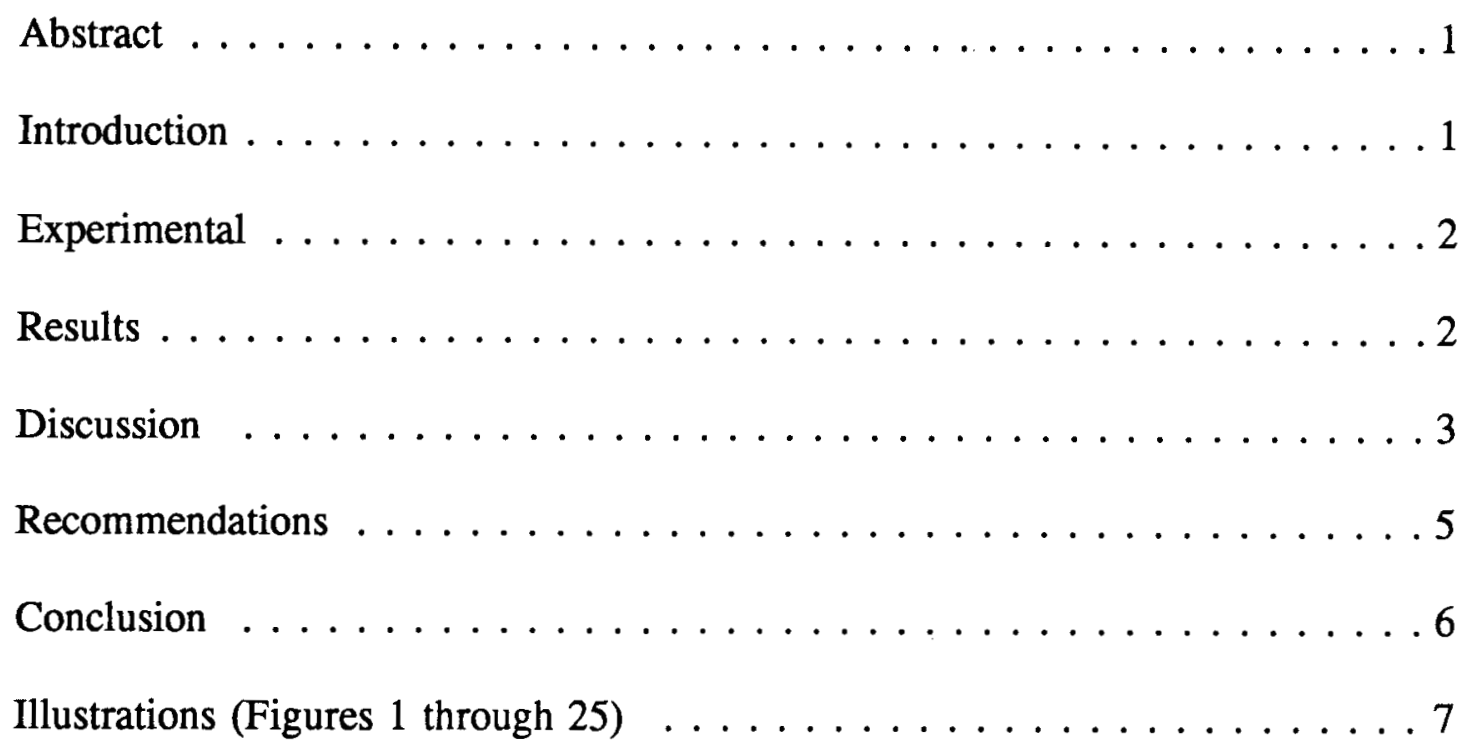


RFP-4552 


\title{
CUTTING TOOL STUDY 21-6-9 STAINLESS STEEL
}

\author{
A. P. McManigle
}

\section{ABSTRACT}

The Rocky Flats Plant conducted a study to test cermet cutting tools by performing machinability studies on War Reserve product under controlled conditions. The purpose of these studies was to determine the most satisfactory tools that optimize tool life, minimize costs, improve reliability and chip control, and increase productivity by performing the operations to specified accuracies.

This study tested three manufacturers' cermet cutting tools and a carbide tool used previously by the Rocky Flats Plant for machining sphericalshaped 21-6-9 stainless steel forgings (Figure 1). The 80-degree diamond inserts were tested by experimenting with various chip-breaker geometries, cutting speeds, feedrates, and cermet grades on the outside contour roughing operation. The cermets tested were manufactured by Kennametal, Valenite, and NTK. The carbide tool ordinarily used for this operation is manufactured by Carboloy. Evaluation of the tools was conducted by investigating the number of passes per part and parts per insert, tool wear, cutting time, tool life, surface finish, and stem taper.

Benefits to be gained from this study were: improved part quality, better chip control, increased tool life and utilization, and greater fabrication productivity. This was to be accomplished by performing the operation to specified accuracies within the scope of the tools tested.

\section{INTRODUCTION}

A visual analysis of the machining operation for the 21-6-9 stainless steel forgings using the specified carbide tool revealed that chip control is extremely poor, tool changes are frequent, and taper of the stem is sometimes excessive. The carbide insert produced snarling chips that are sharp and very hazardous to the operator. The operator must stop the machine frequently to remove chips when they wrap around the part and tool post. These snarling chips also mar the workpiece surface.

The existing Carboloy carbide tool has a life that averages about one and one-half to two parts per cutting edge. The insert also produces edge buildup. This occurs when small work material fragments adhere to the insert edge. When these fragments break away, they carry small pieces of tool material, accelerating wear and insert failure and causing part dimensional and surface finish problems. The taper on the stem can be as much as 0.003 in. This can cause problems in subsequent manufacturing processes.

Eighty-degree diamond inserts from four manufacturers were tested using various chipbreaker geometries, cutting speeds, feedrates, and grades. The three cermets tested were manufactured by Kennametal, NTK, and Valenite. The fourth is the carbide tool, which is manufactured by Carboloy. It continues to be used for this process. See Table 1.

Selection of the cermet cutting tools for this experiment was based on a preliminary study in May 1990. The inserts were tested using 0.020-, 0.040 -, and 0.100 -in. depths of cut, various chipbreaker geometries, and cermet grades. The inserts were run on 304L stainless steel forgings using boring, turning, and facing operations on a Leblond 12/12 lathe. 
TABLE 1. Tools Tested

\begin{tabular}{||l|l|l|c|c||}
\hline Manufacturer & \multicolumn{1}{|c|}{ ID No. } & Grade & $\begin{array}{c}\text { Tool Nose } \\
\text { Radius } \\
\text { (in.) }\end{array}$ & $\begin{array}{c}\text { Back Rack } \\
\text { Angle } \\
\text { (degree) }\end{array}$ \\
\hline Carboloy & CNMP423E 16 & GR550 & 0.031 & 5 \\
\hline Valenite & CNMG432 A6K & VC671 & 0.031 & -5 \\
\hline NTK & CNMG432 (ZW1) & XN4 & 0.031 & -5 \\
\hline Kennametal & CNMP432K & KT150 & 0.031 & 0 \\
\hline
\end{tabular}

\section{EXPERIMENTAL}

The machining operation chosen for this study faces Side 1 of the part and turns the major outside and inside contours. Once this operation is completed, the part is reversed in the chuck to Side 2; then the outside contour and the stem are turned and faced. See Figure 1. Facing and turning operations on the outside contour on Sides 1 and 2 utilize the same style 80-degree diamond insert. However, the tool used to machine Side 1 has a much longer life than the one used to machine Side 2. Rough machining Side 2 produces the major portion of the material removed, compared with the small amount from Side 1. Because of the minimal tool wear produced from machining Side 1, all tools were tested on Side 2.

The inside contour on Side 1 is roughed and semifinished using 35-degree diamond inserts, and the outside contour and stem are also semi-finish machined using 35-degree inserts at approximately 0.005-in. depth of cut. Although 35-degree diamond inserts were not investigated because of lack of time and resources, they will be tested soon.

The lathe used in this study was a CNC Leblond 12/12 Mark II, which rough machines the 21-6-9 stainless steel forging. The machining parameters were varied during the experiment except the depth of cut, which was maintained at 0.030 in. Cutting speeds were 300 and 400 surface feet per minute (sfpm) and the feedrates were 0.0032 and 0.0072 in. per revolution (ipr).
The information used to evaluate the performance of the inserts included: number of passes per part, number of parts per insert, tool wear, cutting time, tool life, chip control, part surface finish, and stem taper.

The inserts were tested by roughing the parts under normal machining conditions. The day shift used a cutting speed of $300 \mathrm{sfpm}$ and feedrate of $0.0032 \mathrm{ipr}$. The second shift used a cutting speed of $400 \mathrm{sfpm}$ and feedrate of $0.0072 \mathrm{ipr}$. Rough machining one part on Side 2 takes 33 passes (approximately ten minutes of cutting time).

The tool holder used to rough machine Side 2 of the part is a Kennametal DCLNL-204D, which has a -5 -degree back rake and side rake angles, +5 degree side relief and end relief angles, -5 -degree side-cutting edge angle, and +5 -degree end-cutting edge angle.

Machining was performed wet with emulsion flood coolant using a Trim-Sol 50:1 concentration. Chip samples were taken for each insert tested under the various machining parameters to evaluate chip type and control. Top and front view photographs were taken to evaluate wear of the tools.

\section{RESULTS}

The Kennametal (Grade KT150), Valenite (Grade VC671), and NTK (Grade XN4) performed well during the experiment. Teledyne Firth Sterling (Grade SD3), NTK (Grade XT3), and Kennametal 
(Grades KT125 and KT175) performed poorly. However, further machining work was needed with the Kennametal (KT150), Valenite (VC671), and NTK (XN4) cermet tools before a final evaluation could be determined.

The first cermet tool tested was the NTK insert run at $400 \mathrm{sfpm}, 0.0072 \mathrm{ipr}$, and 0.030 -in. depth of cut (doc). The insert failed by edge chipping and cratering after $20 \mathrm{~min}$ of cutting. It also displayed 0.001-in. flank wear (Figure 2). The insert had good chip control, as it produced infinite helix chips approximately five inches long (Figure 3).

Figure 4 shows the NTK insert run at $300 \mathrm{sfpm}$, $0.0032 \mathrm{ipr}$, and 0.030 -in. doc. It showed fracture, edge chipping, and 0.0013 -in. flank wear after 30 min of cutting. Chip control was poor (Figure 5). The insert produced continuous snarling chips seven inches long - a hazard and nuisance to the operator.

The next cermet tool tested was a Valenite insert. The machining parameters for the first test were $400 \mathrm{sfpm}, 0.0072 \mathrm{ipr}$, and 0.030 -in. doc. It started to break down after $70 \mathrm{~min}$ on the sidecutting edge (Figure 6). Figure 7 illustrates the excellent chip control this insert produced at these parameters. These chips were easy to manage and posed no hazard to the operator.

The Valenite insert was then run at $300 \mathrm{sfpm}$, $0.0032 \mathrm{ipr}$, and 0.030 -in. doc. The insert fractured after $40 \mathrm{~min}$ cutting on the side-cutting edge (Figure 8). The chip control was extremely poor at these parameters. The insert produced continuous snarling chips that were difficult to handle. The operator had to stop the machine often to remove chips that accumulated around the workpiece and tool post (Figure 9).

The last cermet tested was a Kennametal insert. It fractured on the side-cutting edge after $10 \mathrm{~min}$ at $300 \mathrm{sfpm}, 0.0032 \mathrm{ipr}$, and 0.030-in. doc (Figure 10). It also had poor chip control, producing continuous snarling chips that were difficult to manage (Figure 11).
This Kennametal tool (Figure 12) showed minimal edge chipping and flank wear after $80 \mathrm{~min}$ at 400 sfpm, $0.0072 \mathrm{ipr}$, and 0.030 -in. doc. The insert produced infinite helix chips approximately three inches long. The chips were easy to manage and posed no hazard to the operator (Figure 13).

The current carbide tool ordinarily utilized for this operation is a Carboloy insert. It produced edge chipping from edge buildup, cratering on the rake face, and 0.0037-in. flank wear at $400 \mathrm{sfpm}$, $0.0072 \mathrm{ipr}$, and 0.030 -in. doc after $30 \mathrm{~min}$ of cutting. Flank wear and edge buildup are shown in Figure 14. Figure 15 illustrates the poor chip control the insert produced at these machining parameters.

This Carboloy tool was then run at $300 \mathrm{sfpm}$, $0.0032 \mathrm{ipr}$, and 0.030 -in. doc. It also failed, producing edge chipping caused by edge buildup, cratering on the rake face, and 0.003-in. flank wear after $15 \mathrm{~min}$ (Figure 16). The chip control (Figure 17) deteriorated more with these lower parameters. Sometimes the insert tore the material instead of actually shearing it.

\section{DISCUSSION}

Evaluation of the data received from this study indicates that two of the cermet tools tested show an increase in machining performance over the current carbide tool normally used. The Kennametal cermet tool showed a definite improvement in chip control, increase in tool life, and improved part quality, reliability, and productivity. Likewise, the Valenite cutting tool produced excellent results, significantly improving the process through greater tool life as well as better chip control, productivity, and reliability.

Analysis shows that most tool failure occurs from crater wear, edge buildup, chipping, and fracture. These failure modes are due to the extreme abrasiveness of the 21-6-9 stainless steel forging. Machining abrasive materials causes rapid wear on the flank, top surface, and nose of the insert. It also induces chipping on the cutting edge. 
Crater wear results from an erosion of the insert, creating a depression on the top surface. Over time, the crater will increase, thereby weakening the cutting edge and causing failure.

The edge buildup grows until it reaches a critical size and then breaks off, carrying small pieces of tool material with it. As this edge buildup decreases or increases, it causes a variation in depth of cut, creating irregular surface roughness. Edge buildup greatly influences cutting forces and puts high frictional stress on the tool point. The edge buildup decreases the effective rake angle, which affects the insert's ability to break chips and direct them away from the workpiece. This decrease in effective rake angle, in turn, increases cutting forces by creating greater friction between the chip and the tool.

Some tools tested had more flank wear, partly caused by slower machining parameters or the tool material grade itself. As flank wear increases, it affects part accuracy and surface finish.

The Kennametal and Valenite cermet cutting tools displayed excellent resistance to edge buildup, fracture failure, abrasive wear, and crater wear at the faster machining parameters.

The number of parts produced verses tool type at the high and low machining parameters is shown in Figure 18. Comparison between high and low parameters indicates that the Valenite, Kennametal, and Carboloy tools produced more parts per cutting edge at the higher cutting speed and feedrate. The Kennametal tool produced eight parts before it had to be indexed to a fresh edge, and the Valenite tool produced seven parts. The Carboloy tool produced twice as many parts per cutting edge at the higher cutting speed and feedrate than at the lower parameters.

Higher cutting speeds reduce cutting forces and friction between the chip and the tool. Slower cutting speeds increase cutting forces and frictional heat, thereby accelerating tool wear and aggravating chatter.
A box-and-whisker plot of stem taper verses tool types tested is shown in Figure 19. The Carboloy tool has a large variance of data with $50 \%$ of the taper ranging from 0.0015 to $0.0025 \mathrm{in}$. The Kennametal tool produced a small variation in data with $50 \%$ of the taper ranging from 0.0012 to 0.0015 in. The NTK tool also has a large taper variance, ranging from 0.001 to $0.0021 \mathrm{in}$. The Valenite taper variation is small, ranging from 0.001 to 0.0016 in.

Stem taper verses high and low machining parameters for the number of parts machined by each tool are shown in Figures 20-23. The line chart for the Carboloy tool indicates that the taper increases as the insert machines more parts at both high and low parameters. The Valenite cermet tools averaged about 0.0015 in. of taper at 400 sfpm and $0.0072 \mathrm{ipr}$; but at $300 \mathrm{sfpm}$ and 0.0032 ipr, the taper decreased from 0.0013 to 0.0005 in. (Figure 21). The NTK tool produced a steady taper of 0.002 in. at $400 \mathrm{sfpm}$ and $0.0032 \mathrm{ipr}$ when machining two parts. Another NTK cermet tool produced a taper between 0.0005 and 0.001 in. at $300 \mathrm{sfpm}$ and $0.0032 \mathrm{ipr}$ (Figure 22).

The Kennametal tool produced an average of $0.0015 \mathrm{in}$. taper at $400 \mathrm{sfpm}$ and $0.0072 \mathrm{ipr}$ when machining eight parts. A line was not plotted for low machining parameters, because the Kennametal tool was unable to machine more than one part. Therefore, not enough data could be obtained to give an accurate estimate on the performance (Figure 23).

A box-and-whisker plot of stem diameter verses tool type is illustrated in Figure 24. The Valenite tools vary significantly in stem diameter because of chipping on the cutting edge over time. The Kennametal tools showed the least variation in stem diameter. The Carboloy and NTK tools also showed minimal variation in stem diameter. The nominal stem diameter is 0.375 in; however, most average approximately 0.3760 to 0.3765 in. This slight oversize is due to setup of tool offsets. However, since this is a rough and semi-finish operation, the parts are acceptable. 
RFP-4552

TABLE 2. Tool Cost Considerations

\begin{tabular}{|c|c|c|c|}
\hline Type & $\begin{array}{c}\text { Initial } \\
\text { Cost }\end{array}$ & Changing & $\begin{array}{l}\text { Total Per } \\
\text { Component }\end{array}$ \\
\hline & \multicolumn{3}{|c|}{ (dollars) } \\
\hline \multicolumn{4}{|l|}{ NTK } \\
\hline CNMG432(ZW1)XN4 & 6.10 & & \\
\hline $300 \mathrm{sfpm}, 0.0032 \mathrm{ipr}$ & & 1.00 & 0.51 \\
\hline 400 sfpm, 0.0072 ipr & & 1.50 & 0.75 \\
\hline \multicolumn{4}{|l|}{ Valenite } \\
\hline CNMG432 A6K (VC671) & 4.80 & & \\
\hline $300 \mathrm{sfpm}, 0.0032 \mathrm{ipr}$ & & 0.67 & 0.26 \\
\hline $400 \mathrm{sfpm}, 0.0072 \mathrm{ipr}$ & & 0.43 & 0.17 \\
\hline \multicolumn{4}{|l|}{ Kennametal } \\
\hline CNMP432K (KT150) & 5.27 & & \\
\hline $300 \mathrm{sfpm}, 0.0032 \mathrm{ipr}$ & & 3.00 & 1.32 \\
\hline $400 \mathrm{sfpm}, 0.0072 \mathrm{ipr}$ & & 0.37 & 0.16 \\
\hline \multicolumn{4}{|l|}{ Carboloy } \\
\hline CNMP432E 16 (GR550) & 7.80 & & \\
\hline $300 \mathrm{sfpm}, 0.0032 \mathrm{ipr}$ & & 2.00 & 1.30 \\
\hline $400 \mathrm{sfpm}, 0.0072 \mathrm{ipr}$ & & 1.00 & 0.65 \\
\hline
\end{tabular}

Figure 25 (box-and-whisker plot on stem diameter verses fast and slow machining parameters) also indicates that setting of offsets varies between day and second shifts. Figures 24 and 25 indicate tool wear causes variations in stem diameter over time.

Analysis of the tool costs, tool changing costs, and tool costs per component between the inserts and machining parameters indicates a significant economic benefit. See Table 2. Running higher cutting speeds and feedrates for three tools tested shows a definite reduction in tool changing costs and tool cost per component. However, this does not apply to the NTK cermet tool, which requires more tool changing and tool cost per component because of premature edge failure at the increased machining parameters. The Kennametal cermet tool shows an approximate $3: 1$ reduction in tool changing costs and $4: 1$ reduction in tool costs per component when compared with the Carboloy carbide tool at $400 \mathrm{sfpm}$ and $0.0072 \mathrm{ipr}$. The Valenite also has excellent cost benefits at higher machining parameters.

\section{RECOMMENDATIONS}

It is recommended that the Kennametal cermet cutting tool be utilized as the primary insert to rough the 21-6-9 stainless steel forging components. The data show that this tool performs best at a cutting speed and feedrate of $400 \mathrm{sfpm}$ and 0.0072 ipr. These parameters prevent premature tool failure, improve chip control, and reduce 
RFP-4552

cutting forces, thereby producing less taper on the stem caused by excessive chatter and tool wear.

If the Kennametal cermet tool cannot be utilized, we recommend the Valenite cermet tool. It should be run at no less than $400 \mathrm{sfpm}$ and $0.0072 \mathrm{ipr}$. Any tool used for this roughing operation should be run at no less than the required specifications. Otherwise, premature tool failure will occur, poor chip control will result, edge buildup will develop, and high cutting forces will induce chatter.

\section{CONCLUSION}

Evaluation of the tests results documented from this study indicate that the Kennametal cermet tool is the most reliable for machining the 21-6-9 stainless steel forging in question. It optimizes the machining operation by increasing tool life, part quality, and productivity, as well as reducing total minimum cost and improving chip control beyond the specified requirements. The Valenite tool is a viable alternative. 


\section{ILLUSTRATIONS (Figures 1 through 25)}

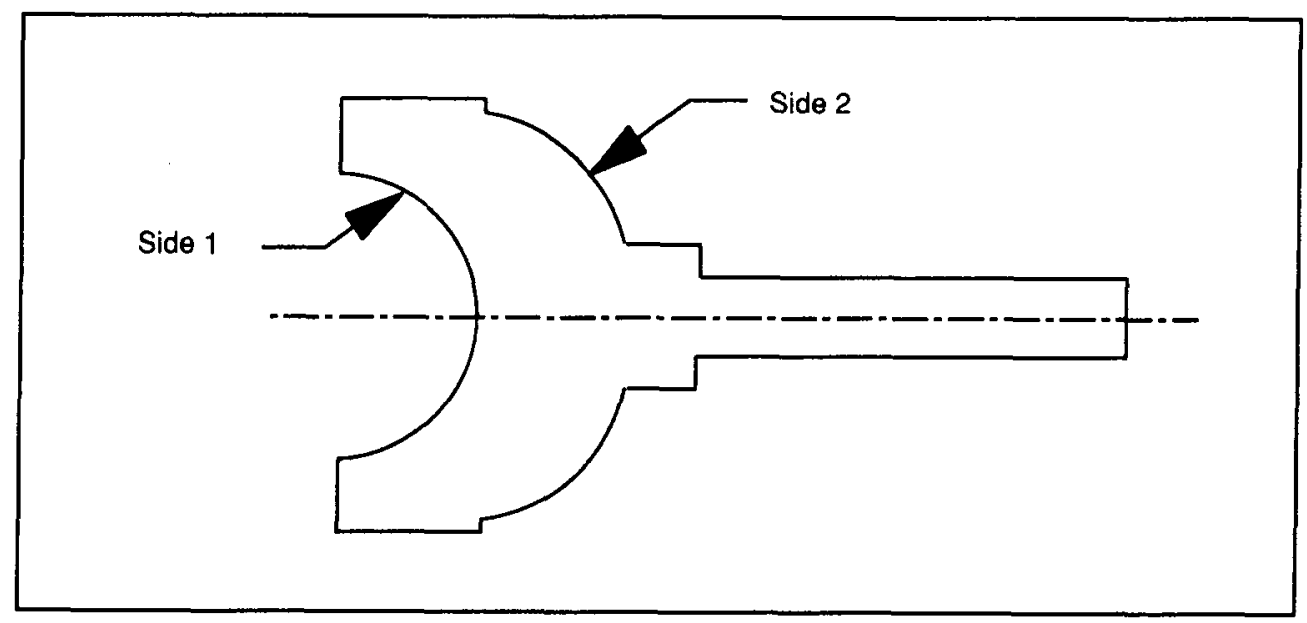

FIGURE 1. Spherical-Shaped Part
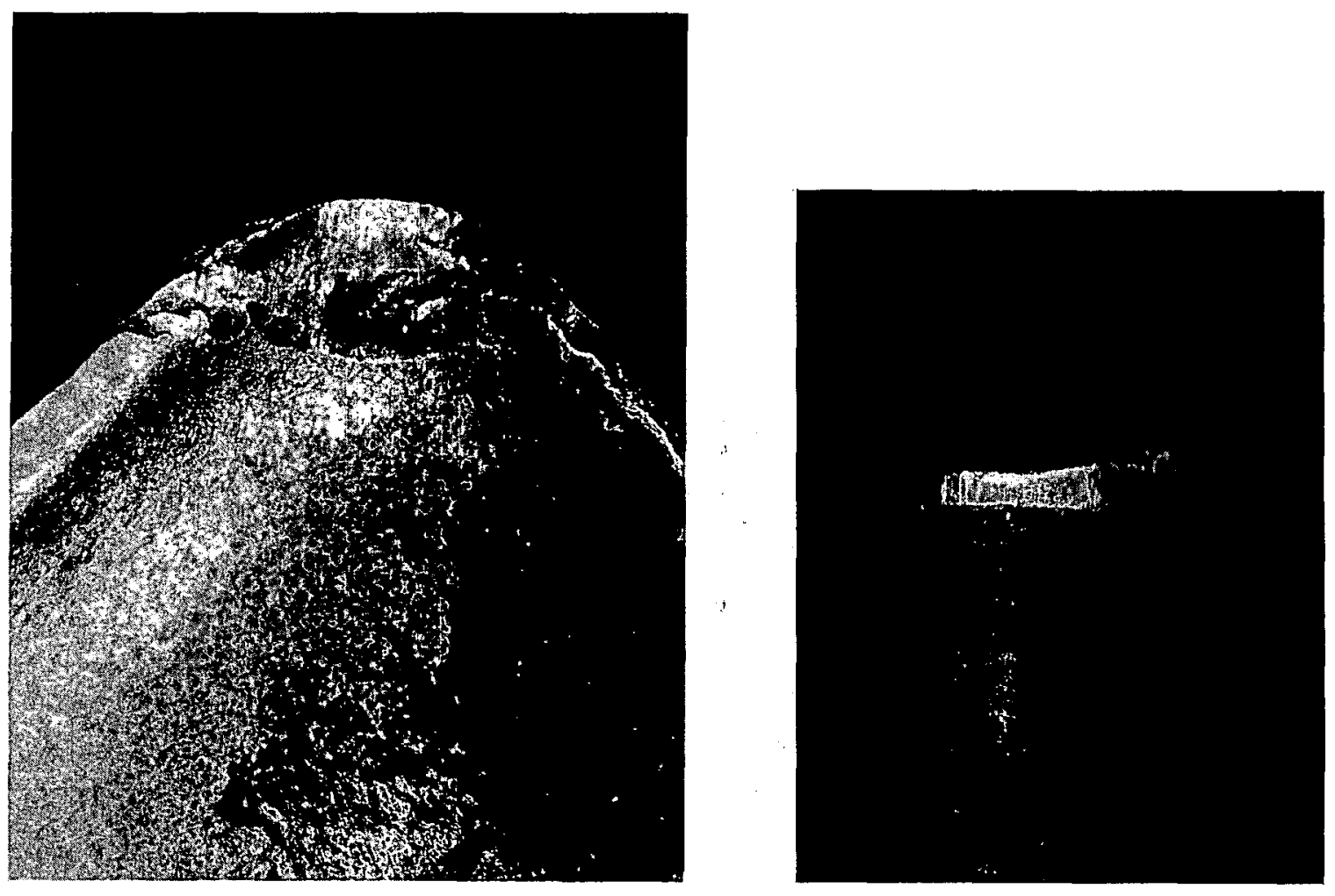

41412-17

FIGURE 2. NTK Insert. This tool produced edge chipping and cratering on the rake face and showed 0.001 -in. flank wear after $20 \mathrm{~min}$ at $400 \mathrm{sfpm}, 0.0072 \mathrm{ipr}$, and 0.030-in. doc. 


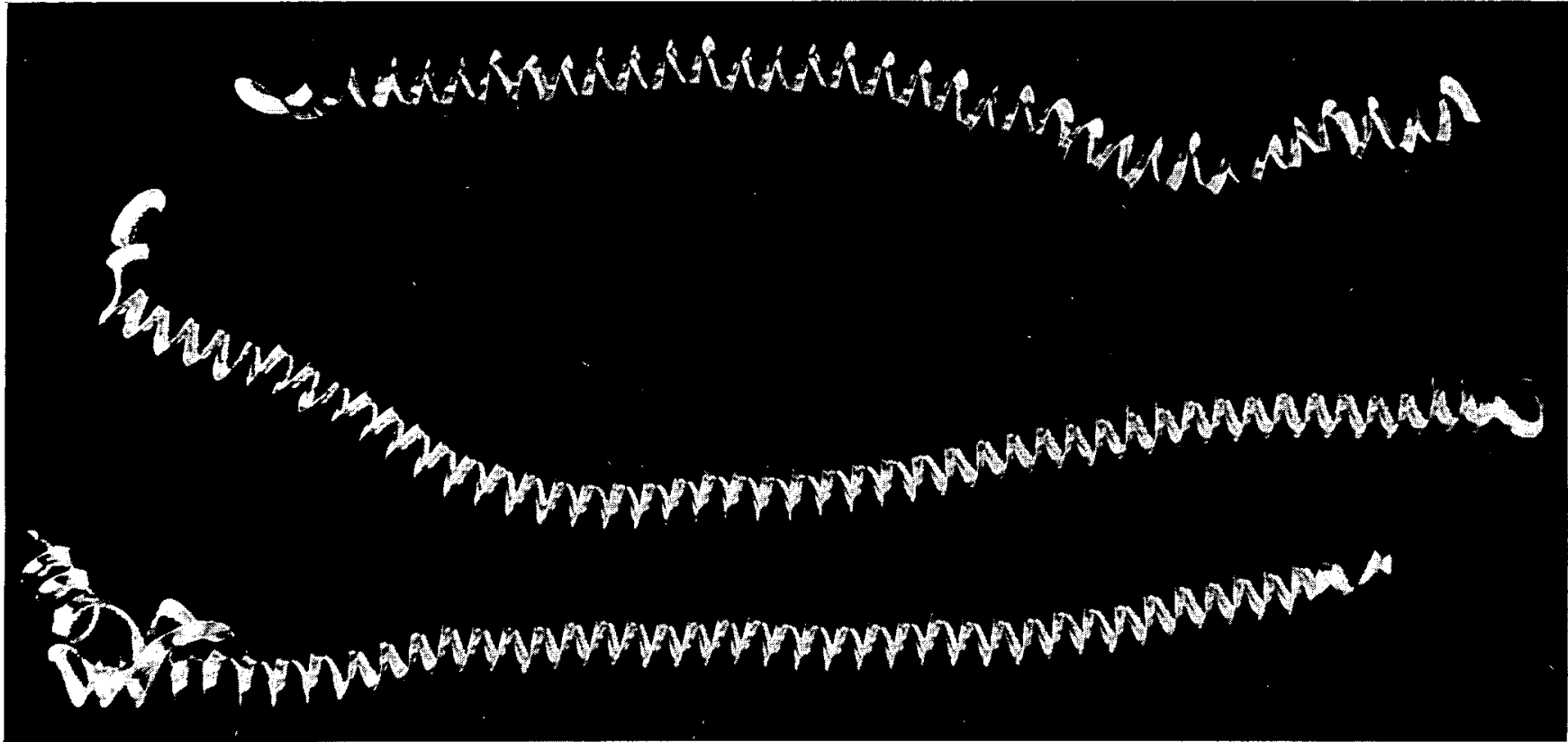

FIGURE 3. NTK Insert. Chip control was good. This tool produced infinite helix chips five inches long at $400 \mathrm{sfpm}$ and $0.0072 \mathrm{ipr}$.
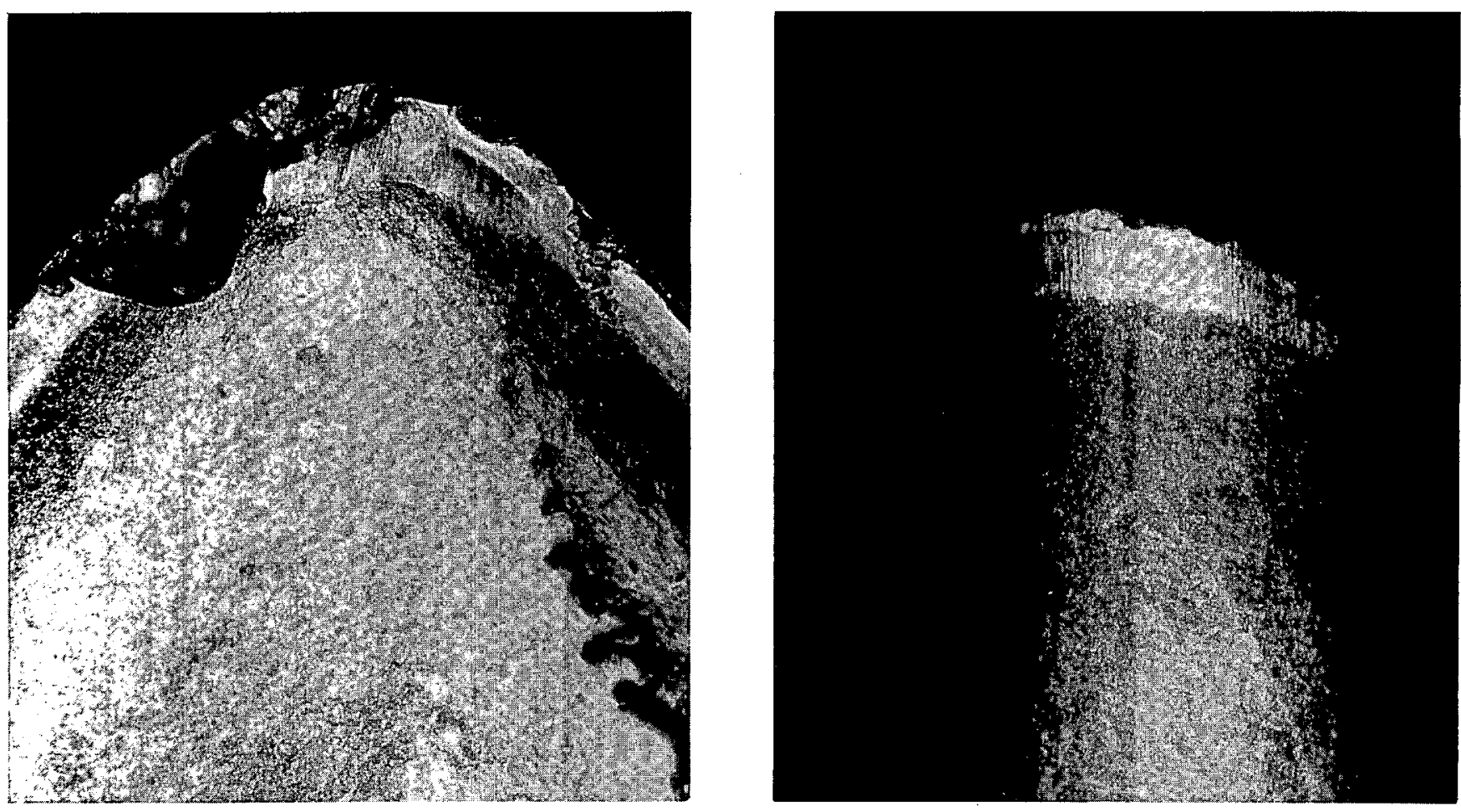

41412-11

FIGURE 4. NTK Insert. This tool produced fracture and edge chipping and displayed 0.0013 -in. flank wear after $30 \mathrm{~min}$ at $300 \mathrm{sfpm}, 0.0032 \mathrm{ipr}$, and 0.030 -in. doc. 


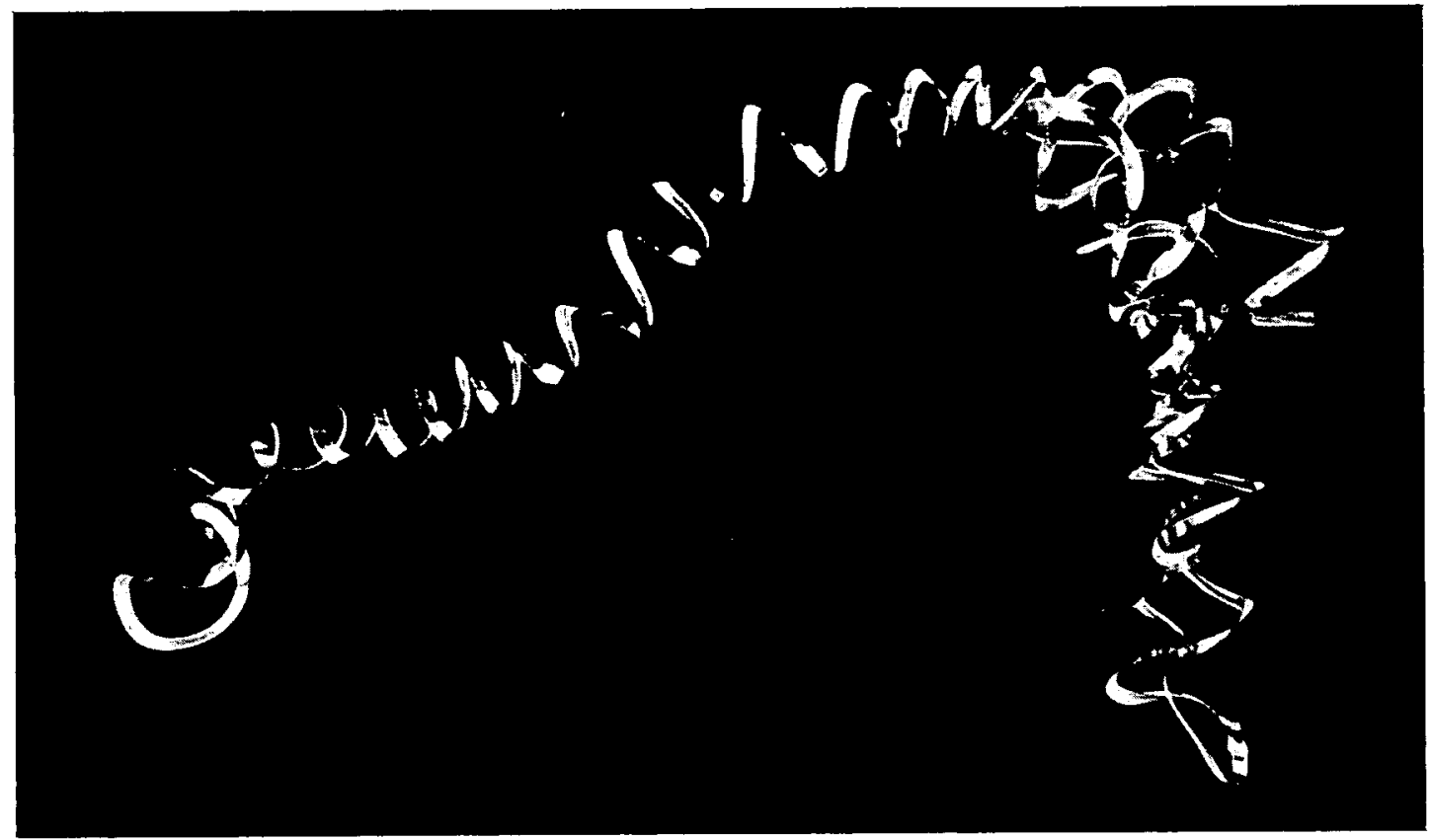

FIGURE 5. NTK Insert. Chip control was poor. The insert produced continuous snarling chips approximately seven inches long at $300 \mathrm{sfpm}$ and $0.0032 \mathrm{ipr}$.
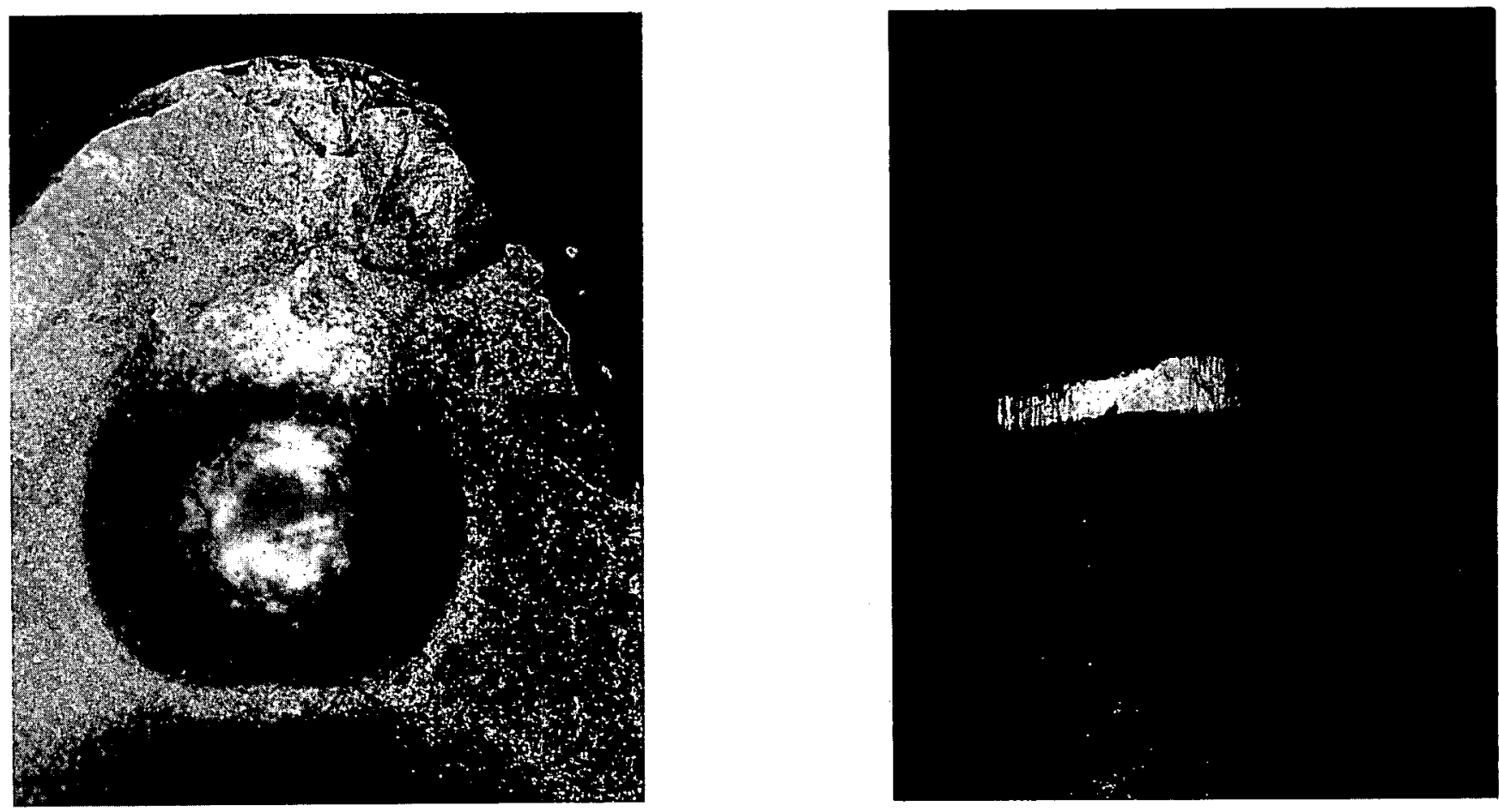

$41412-16$

FIGURE 6. Valenite Insert. This tool produced fracture and edge chipping. It showed 0.0006-in. flank wear after $70 \mathrm{~min}$ at $400 \mathrm{sfpm}, 0.0072 \mathrm{ipr}$, and 0.030-in doc. 


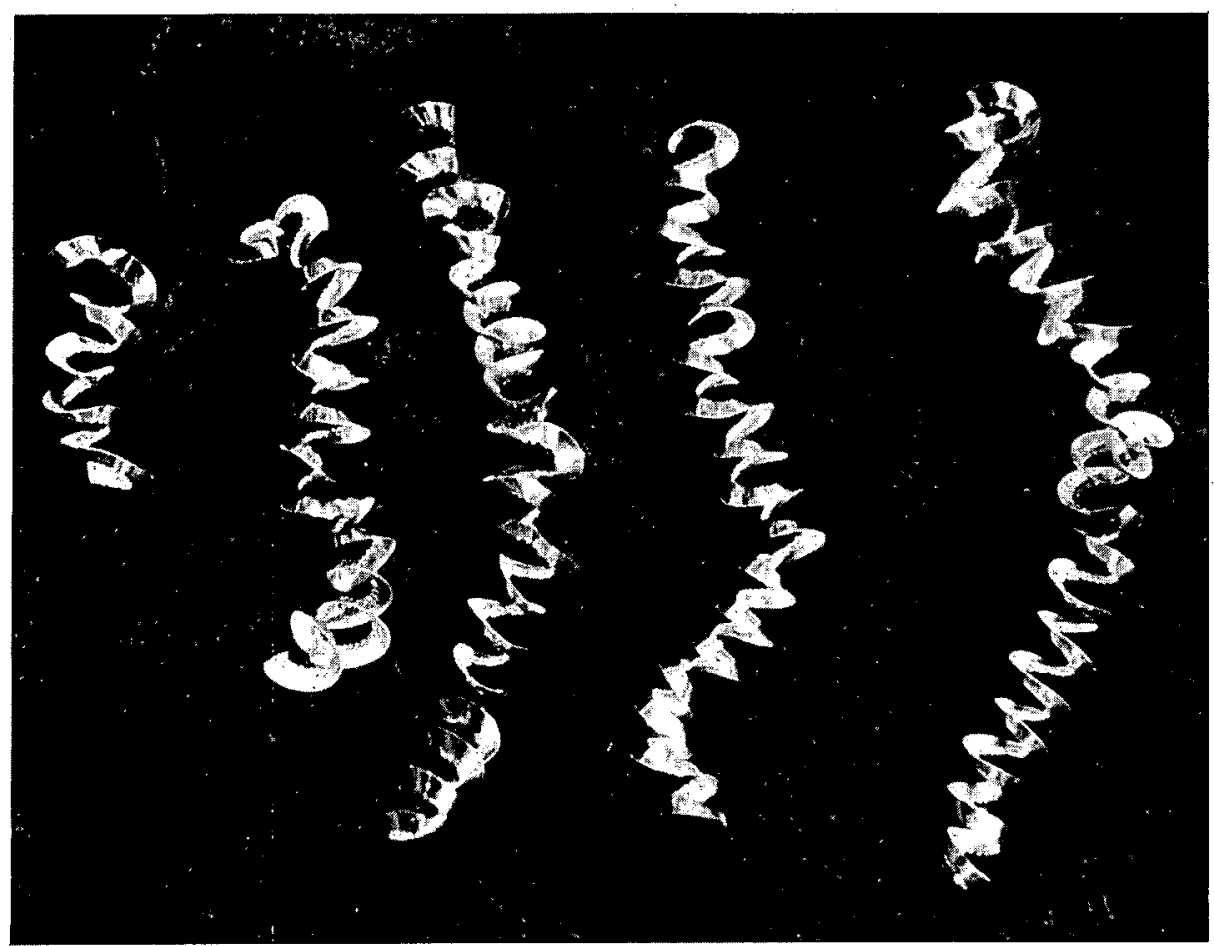

41355-03

FIGURE 7. Valenite Insert. Chip control was excellent. The insert produced infinite helix chips one to two inches long at $400 \mathrm{sfpm}$ and $0.0072 \mathrm{ipr}$.
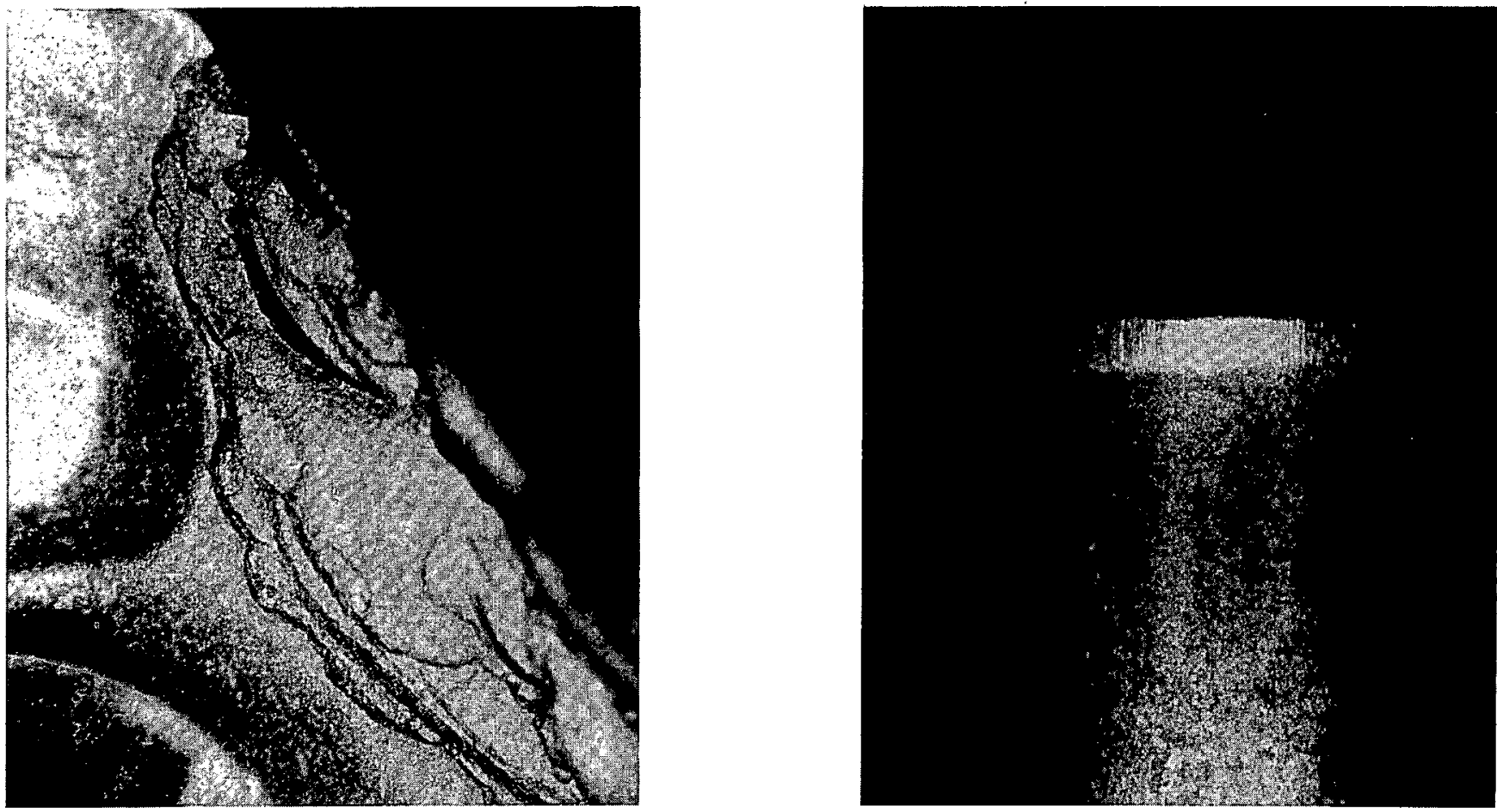

41412-14

FIGURE 8. Valenite Insert. This tool fractured after $40 \mathrm{~min}$ at 300 sfpm, $0.0032 \mathrm{ipr}$, and 0.030 -in doc. It showed 0.0006 -in. flank wear. 


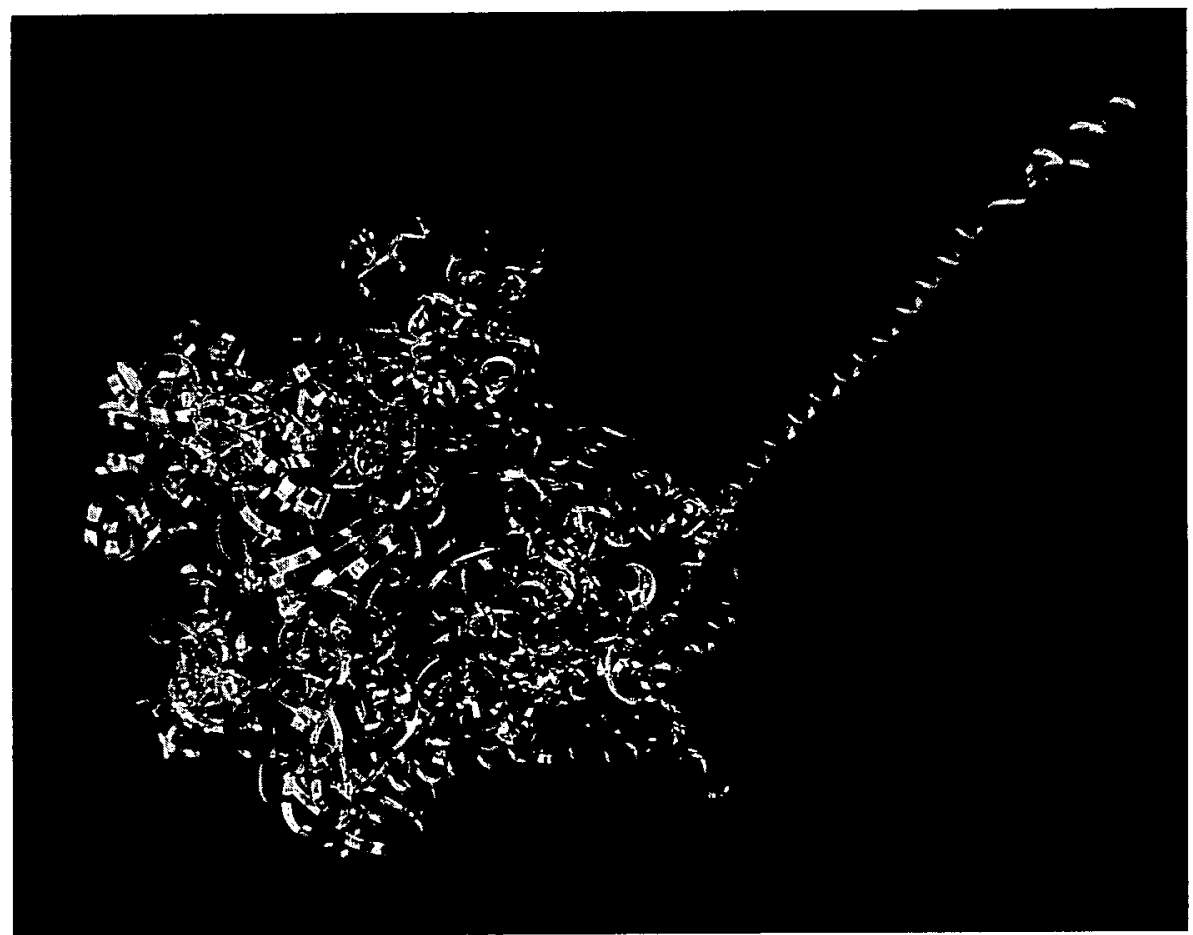

41356-18

FIGURE 9. Valenite Insert. Chip control was extremely poor. The insert produced snarling chips at $300 \mathrm{sfpm}$ and $0.0032 \mathrm{ipr}$.
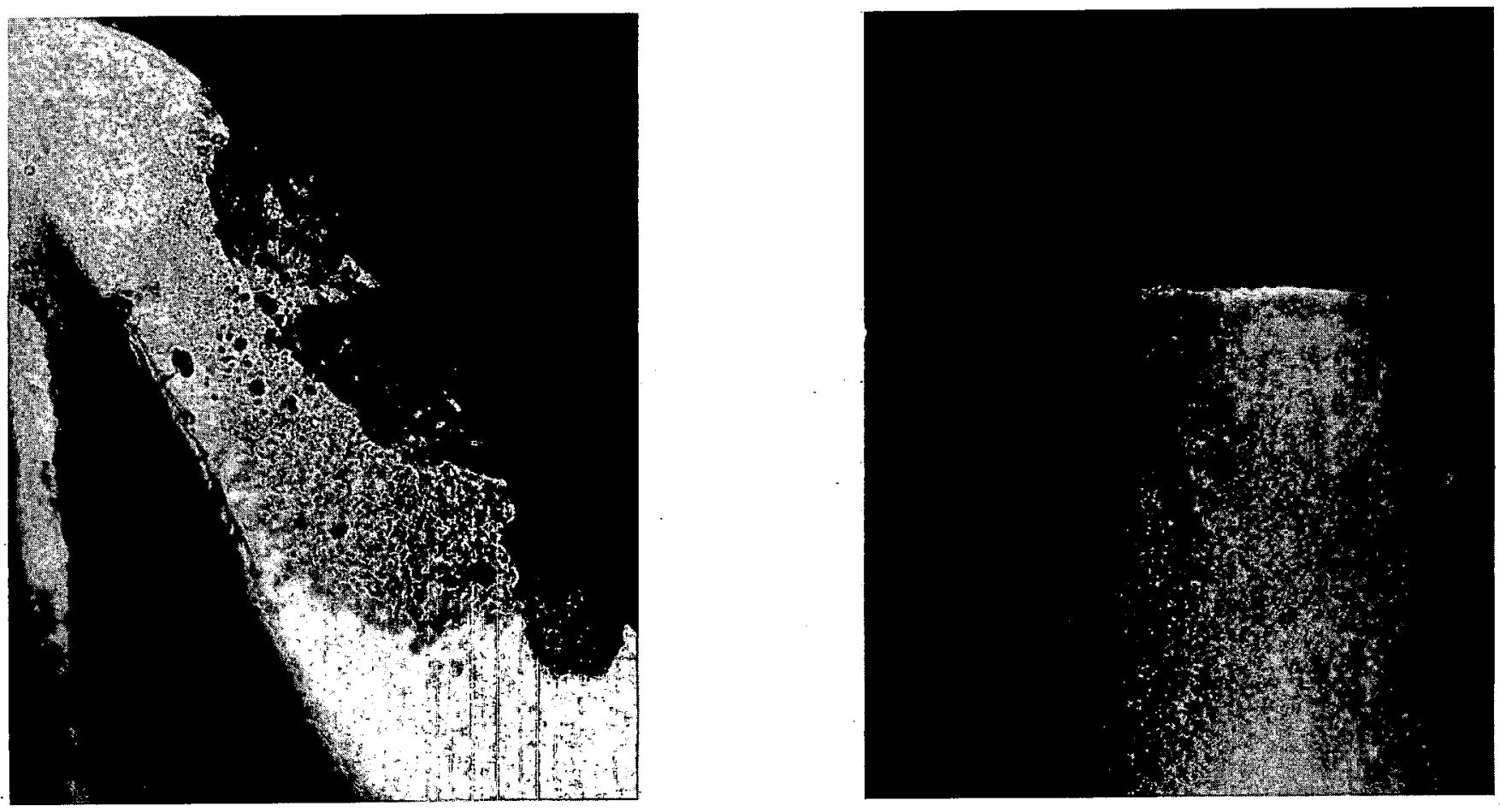

41412-19

41413-19

FIGURE 10. Kennametal Insert. This tool fractured and showed 0.0003-in. flank wear after $10 \mathrm{~min}$ at $300 \mathrm{sfpm}, 0.0032 \mathrm{ipr}$, and 0.030 -in. doc. 
RFP-4552

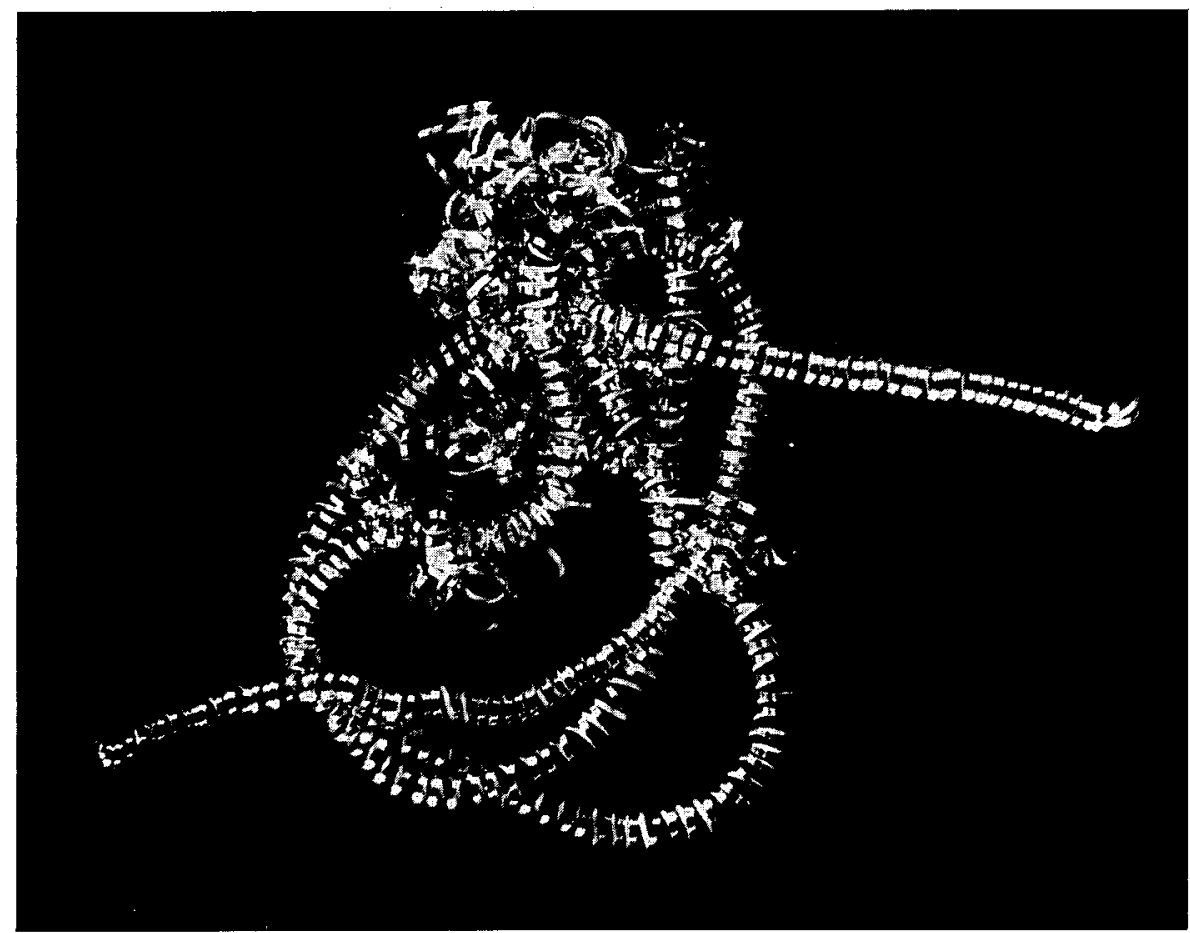

41355-07

FIGURE 11. Kennametal Insert. Chip control was poor. The insert produced snarling chips at $300 \mathrm{sfpm}$ and $0.0032 \mathrm{ipr}$.

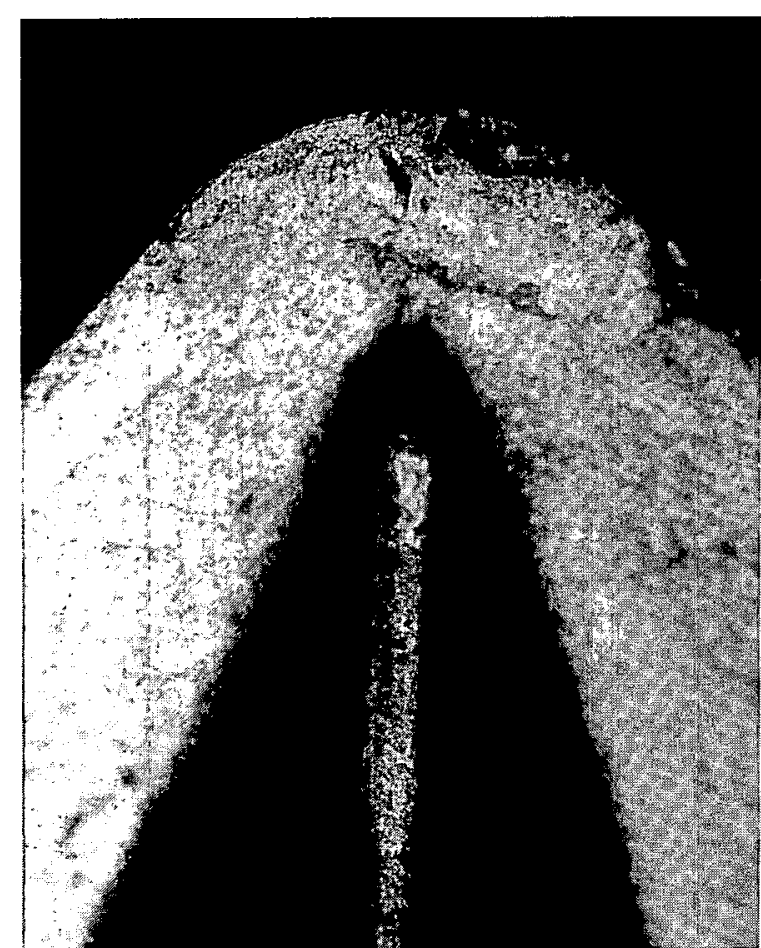

$41412-13$

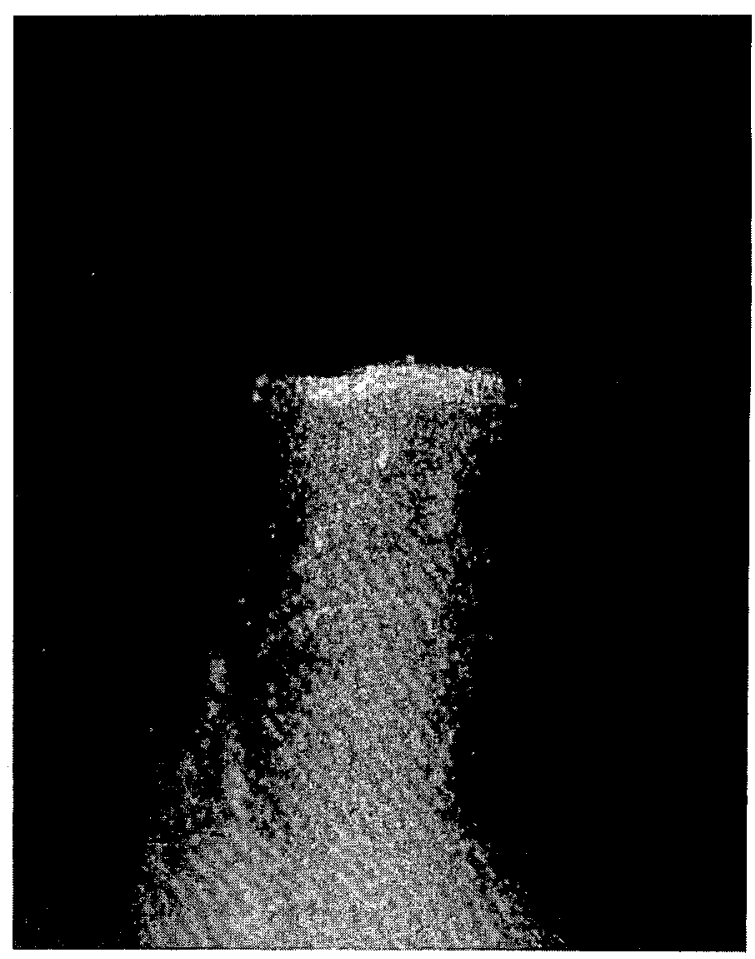

$41412-23$

FIGURE 12. Kennametal Insert. This tool produced some edge chipping and 0.0002 in. flank wear after $80 \mathrm{~min}$ at $400 \mathrm{sfpm}, 0.0072 \mathrm{ipr}$, and $0.030 \mathrm{doc}$. 


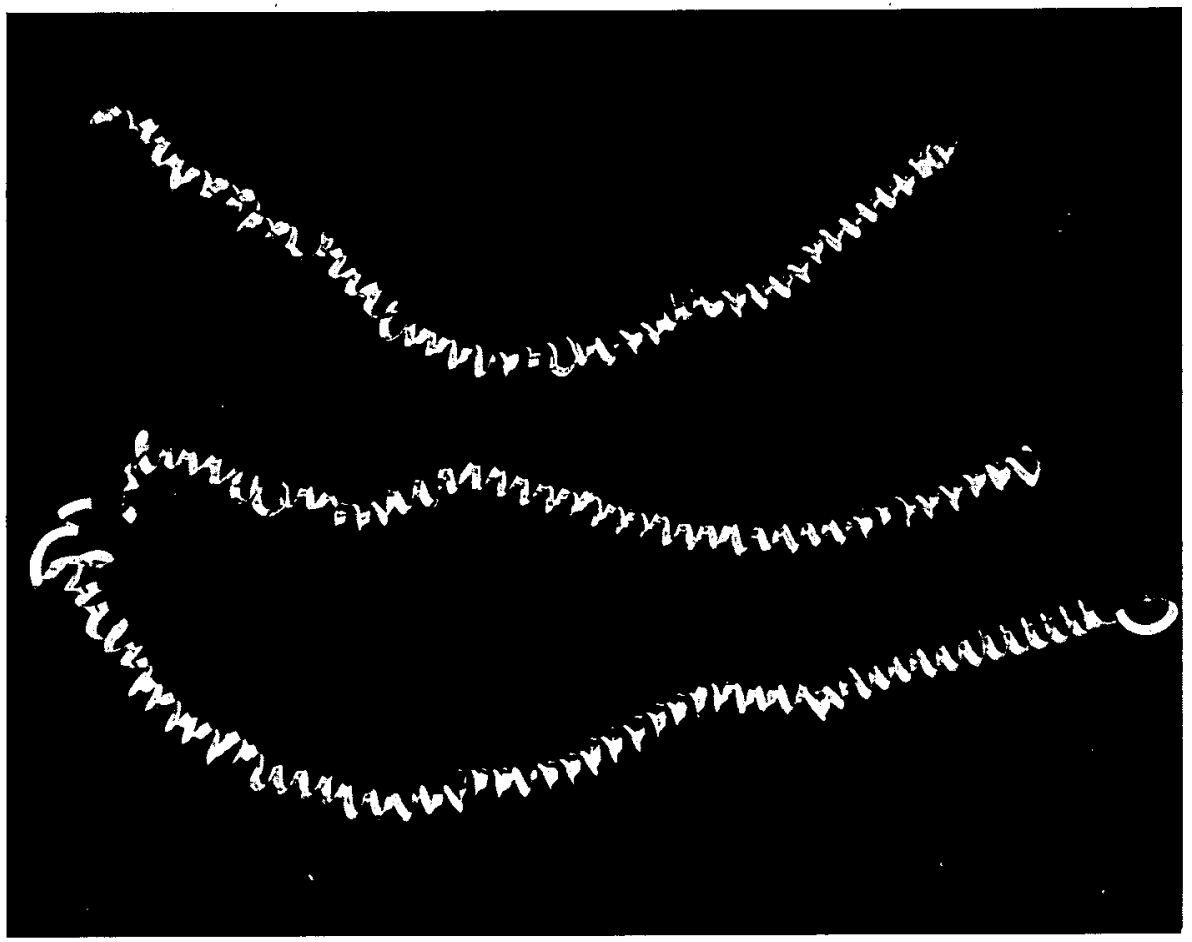

41356-17

FIGURE 13. Kennametal Insert. Chip control was excellent. The insert produced infinite helix chips three to four inches long at $400 \mathrm{sfpm}$ and $0.0072 \mathrm{ipr}$.

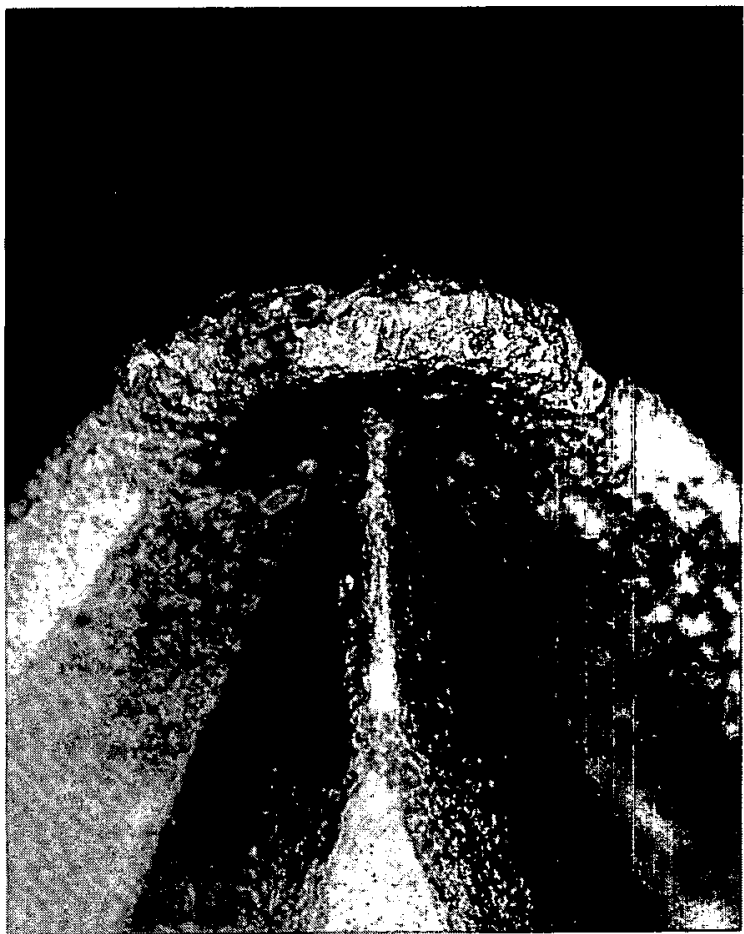

$41412-18$

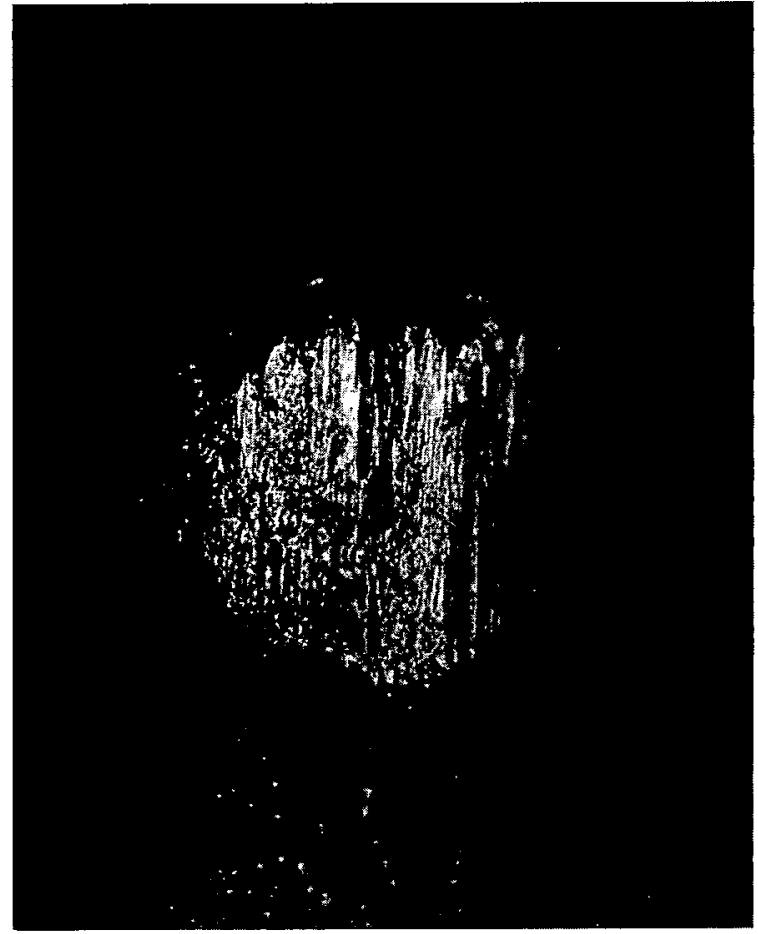

$41413-12$

FIGURE 14. Carboloy Insert. This tool produced edge chipping from edge buildup, cratering on the rake face, and 0.0037-in. flank wear after $30 \mathrm{~min}$ at $400 \mathrm{sfpm}, 0.0072 \mathrm{ipr}$, and 0.030 -in doc. 


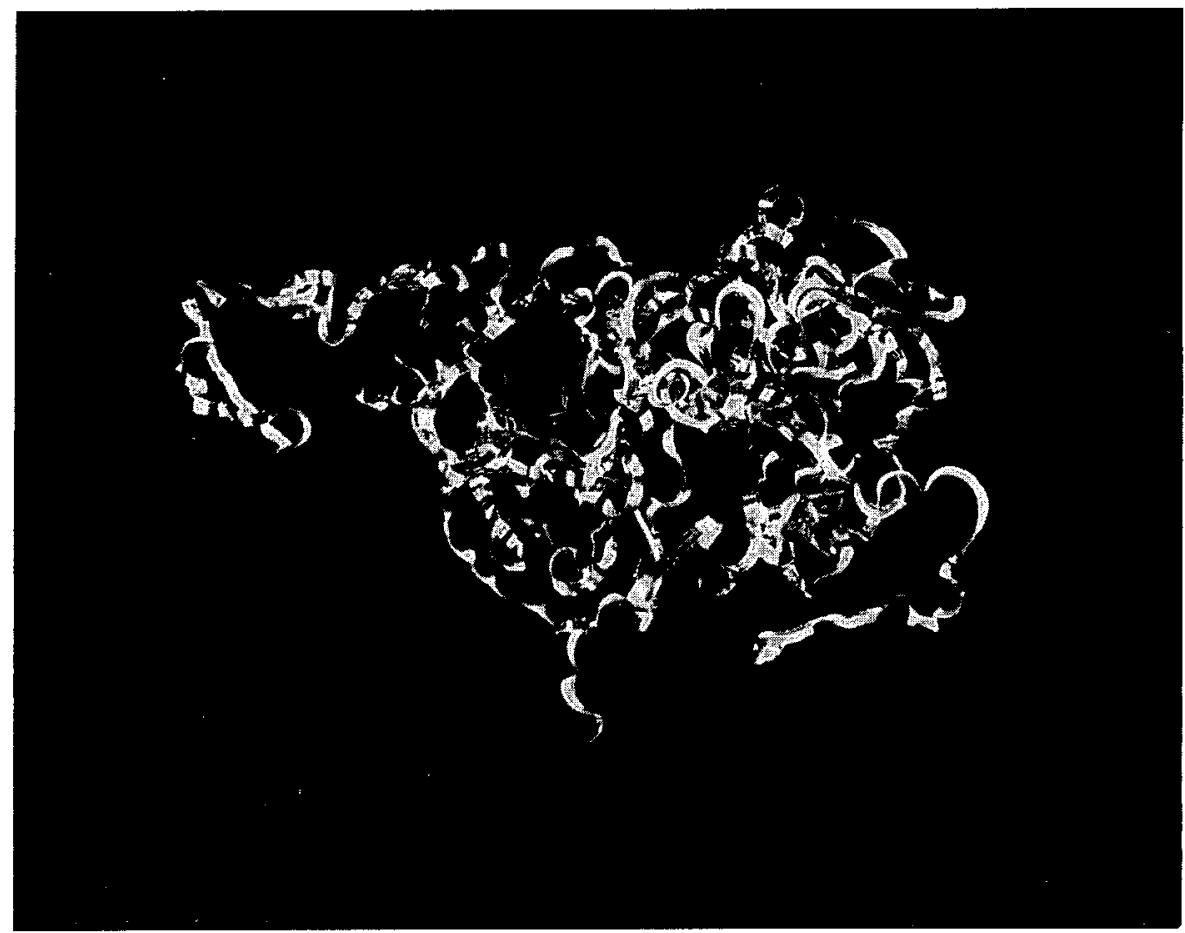

41355-06

FIGURE 15. Carboloy Insert. Chip control was poor. The insert produced snarling chips at $400 \mathrm{sfpm}$ and $0.0072 \mathrm{ipr}$.

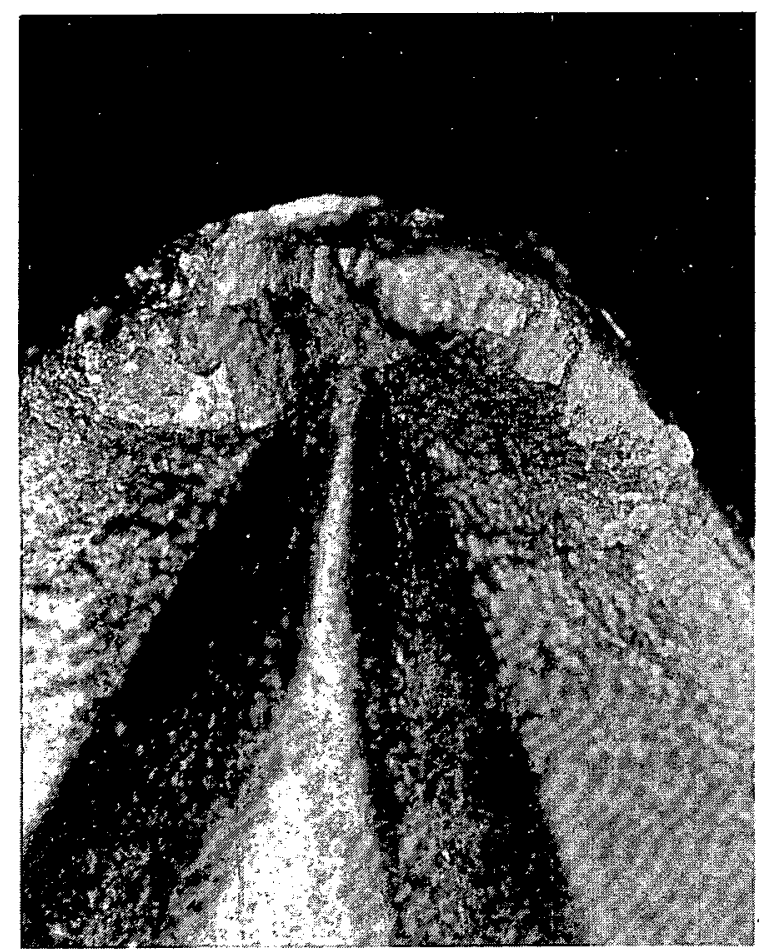

$41412-15$

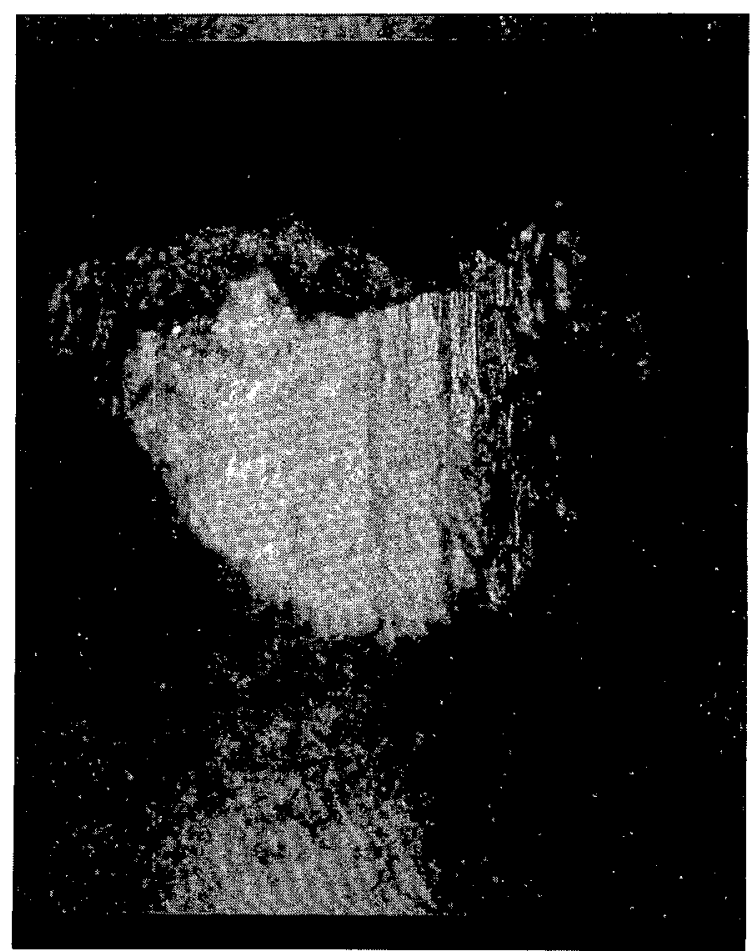

$41412-25$

FIGURE 16. Carboloy Insert. This tool produced edge chipping from edge buildup, cratering on the rake face, and 0.003-in. flank wear after $15 \mathrm{~min}$ at $300 \mathrm{sfpm}, 0.0032 \mathrm{ipr}$, and 0.030 -in. doc. 


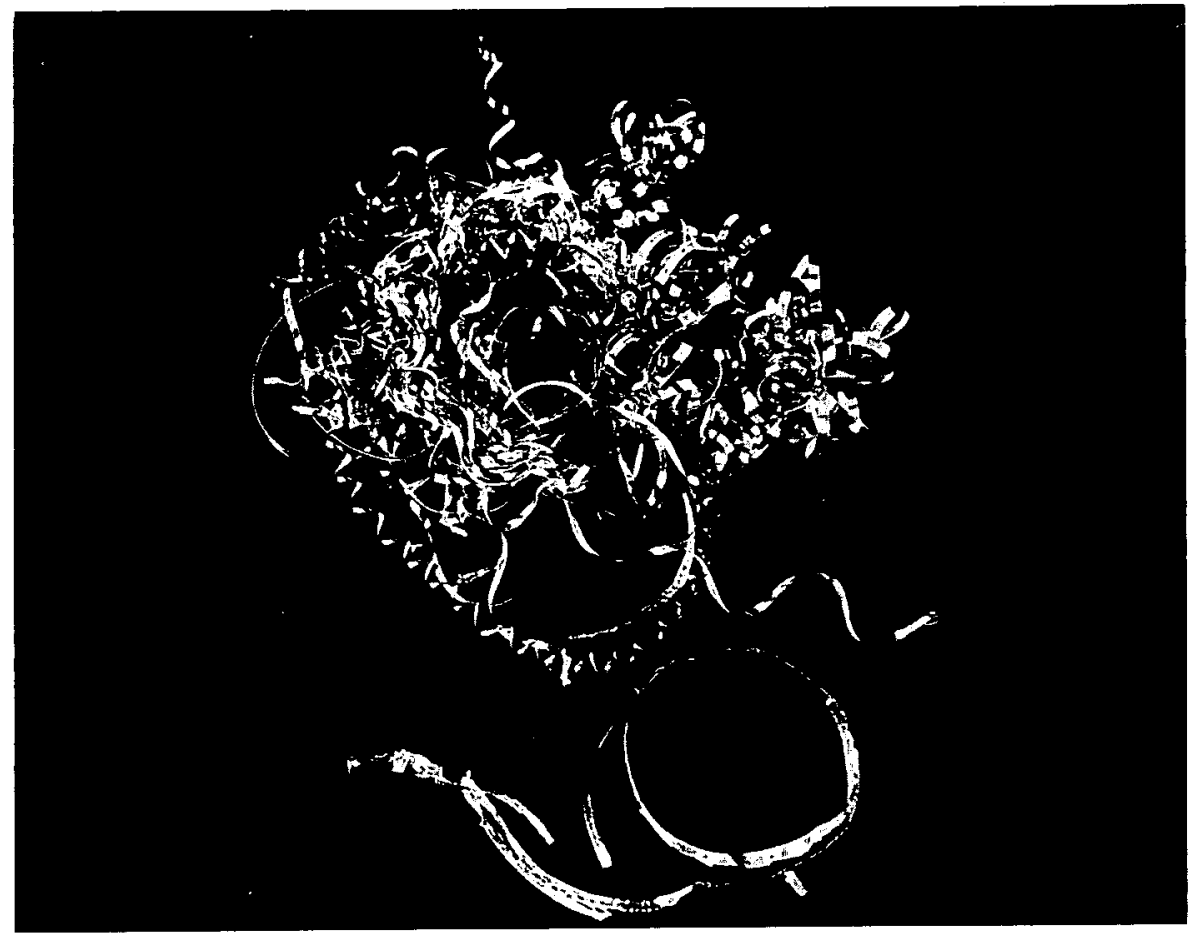

$41355-01$

FIGURE 17. Carboloy Insert. Chip control was extremely poor. The insert produced snarling chips at $300 \mathrm{sfpm}$ and $0.0032 \mathrm{ipr}$.

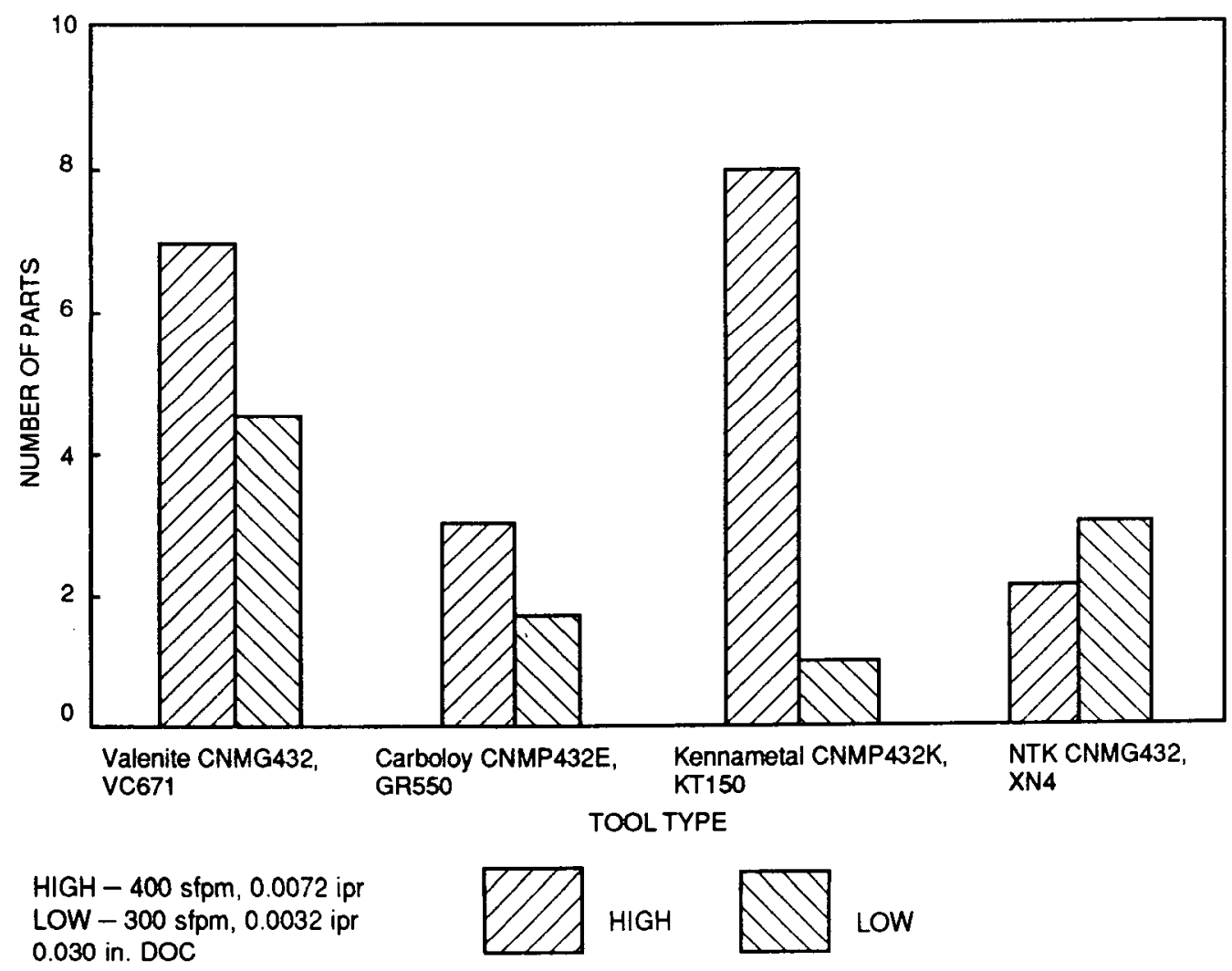

FIGURE 18. Number of Parts Versus Tool Type 
RFP-4552

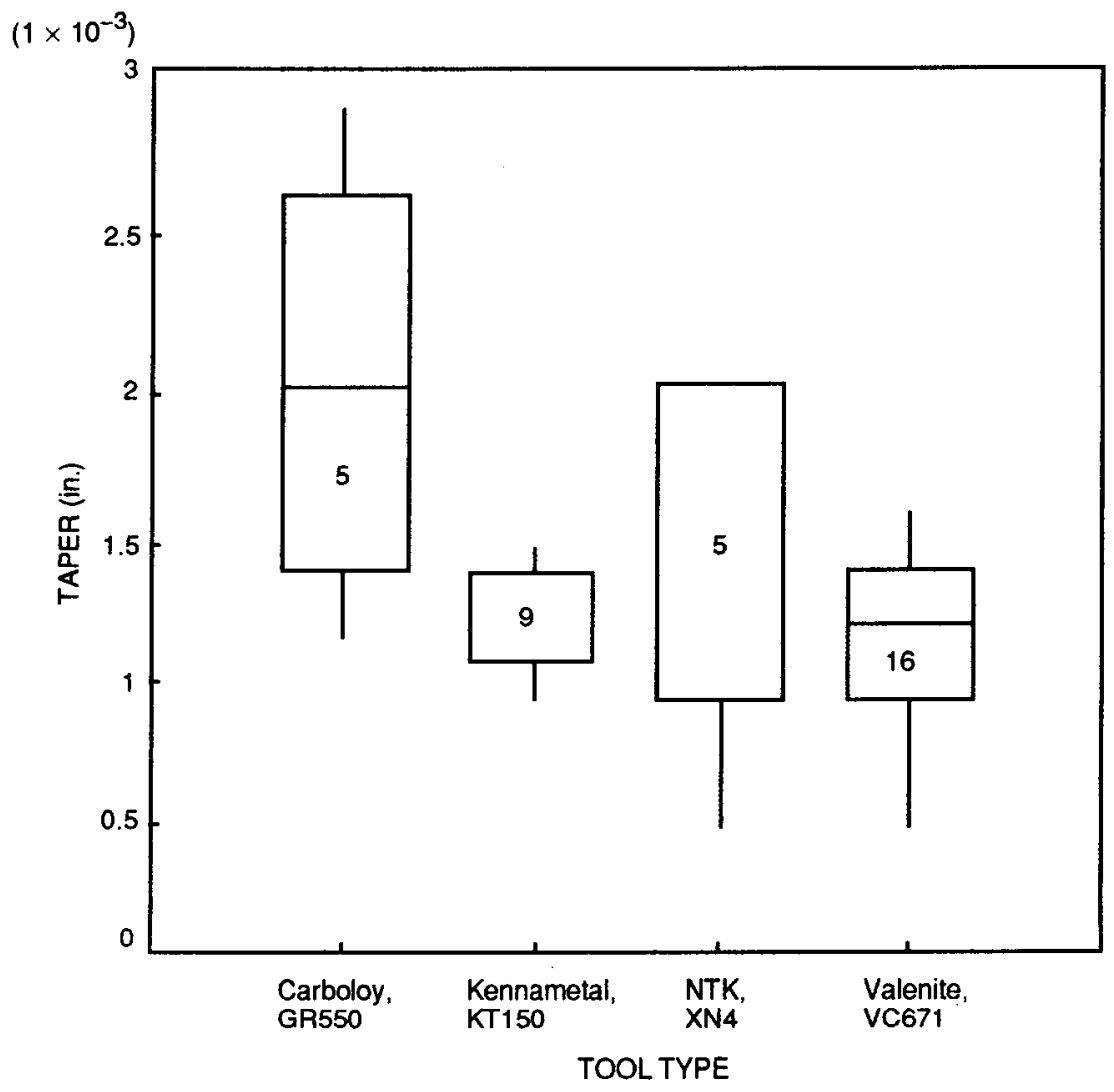

FIGURE 19. Outside Contour Stem Taper Plots

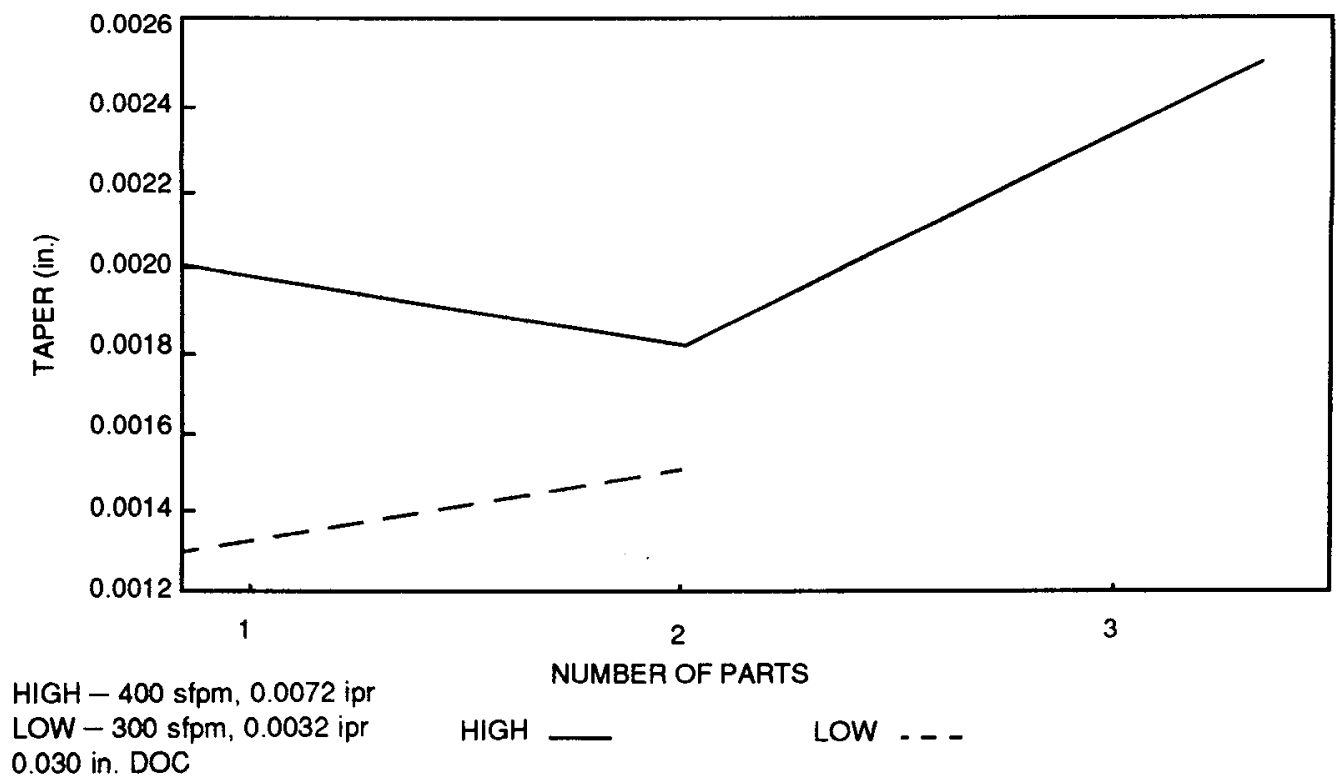

FIGURE 20. Taper on Stem Versus High and Low Parameters. Carboloy Insert. 
RFP-4552

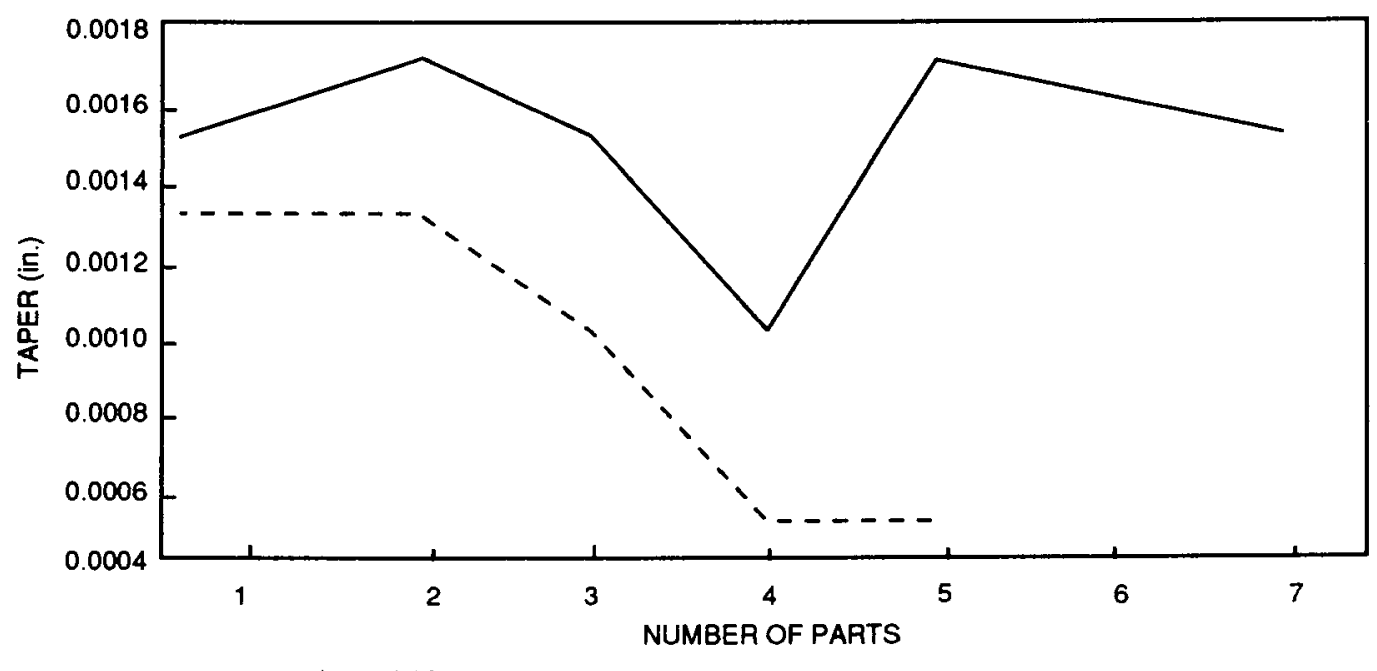

HIGH -400 sfpm, $0.0072 \mathrm{ipr}$

LOW -300 sfpm, $0.0032 \mathrm{ipr}$

0.030 in. DOC

FIGURE 21. Taper on Stem Versus High and Low Parameters. Valenite Insert.

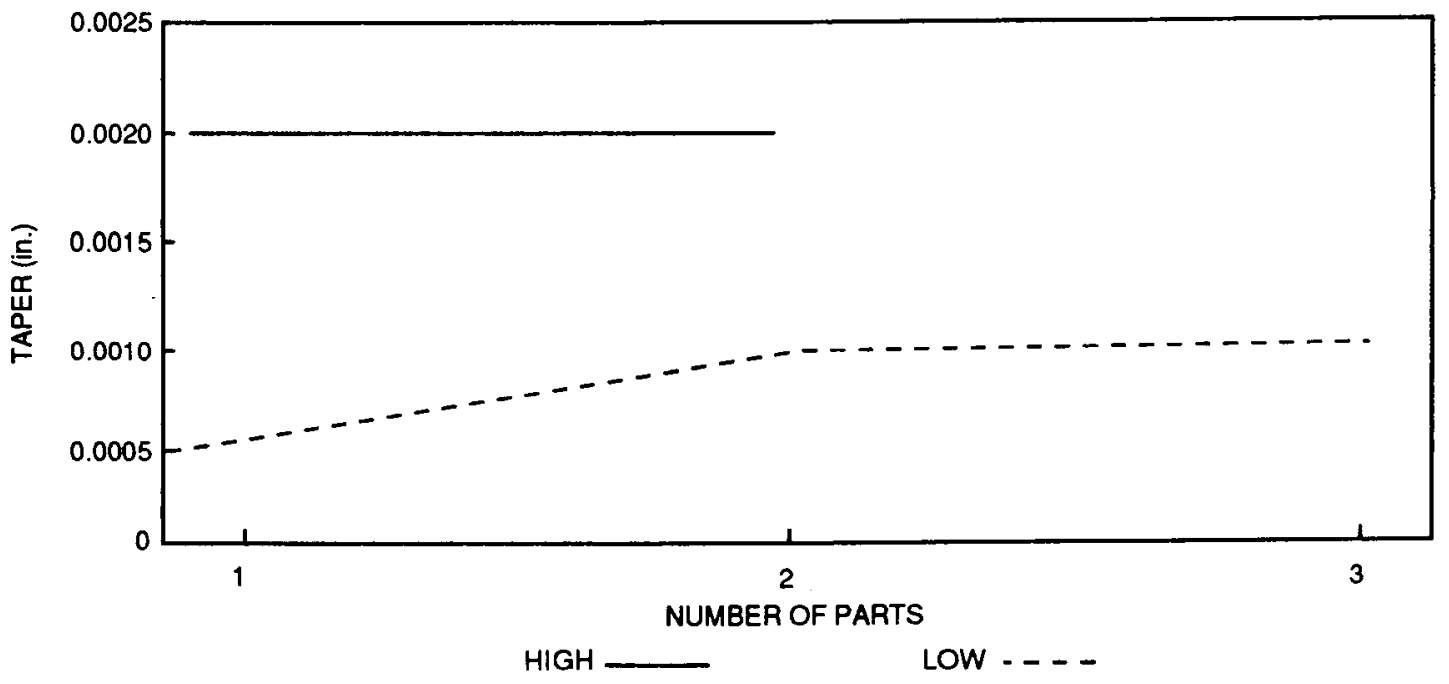

HIGH -400 stpm, $0.0072 \mathrm{ipr}$ LOW $-300 \mathrm{sfpm}, 0.0032 \mathrm{ipr}$ 0.030 in. DOC

FIGURE 22. Taper on Stem Versus High and Low Parameters. NTK Insert. 


\section{RFP-4552}

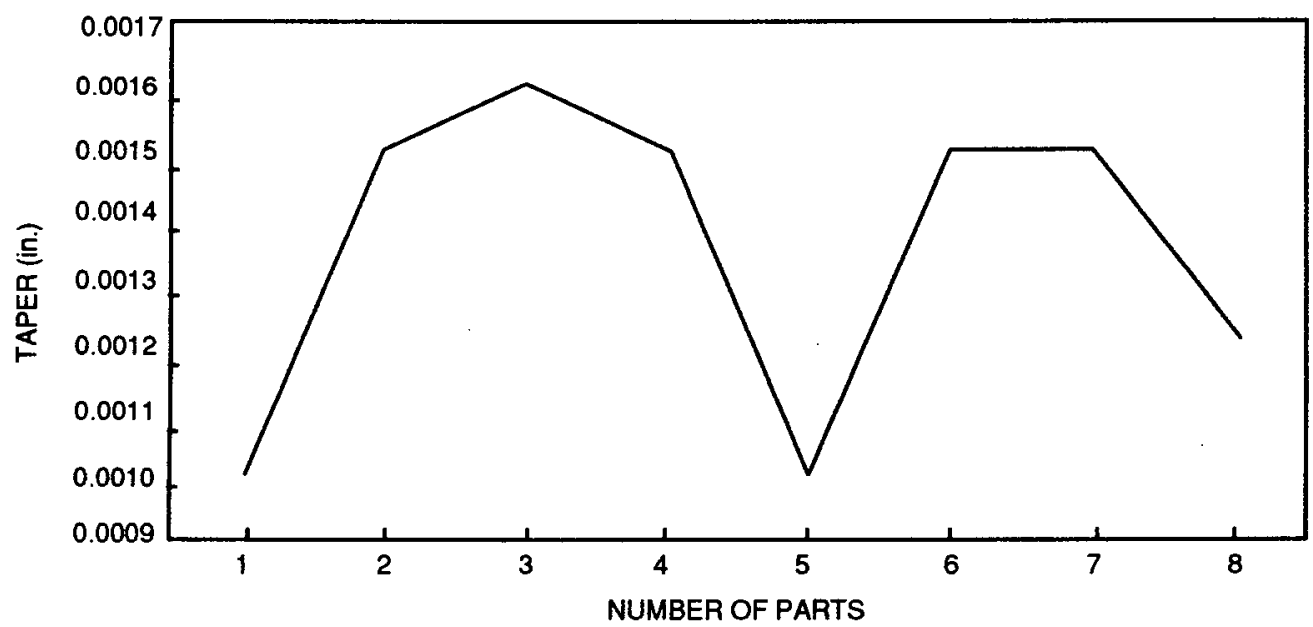

HIGH -400 sfpm, 0.0072 ipr

LOW $-300 \mathrm{sfpm}, 0.0032 \mathrm{ipr}$

0.030 in. DOC

FIGURE 23. Taper on Stem Versus High and Low Parameters. Kennametal Insert.

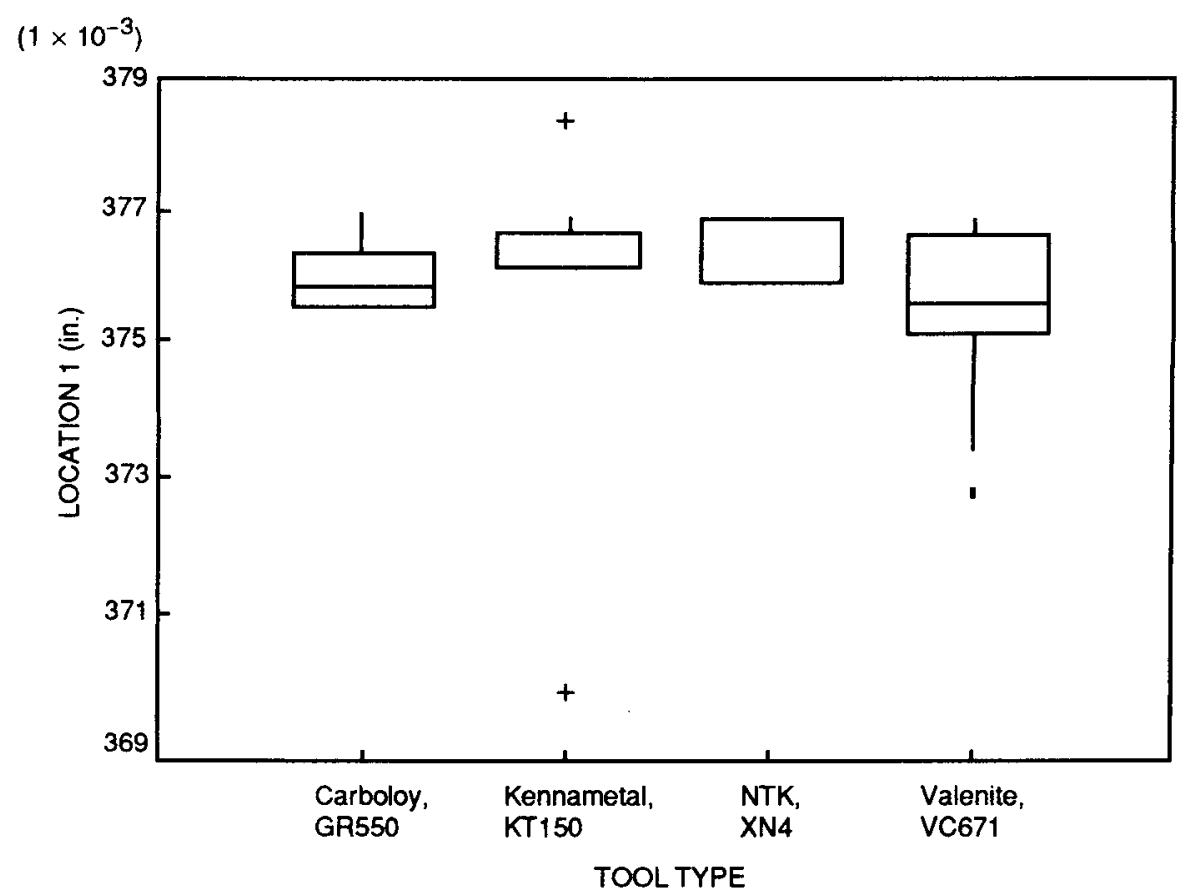

FIGURE 24. Stem Diameter Evaluation 


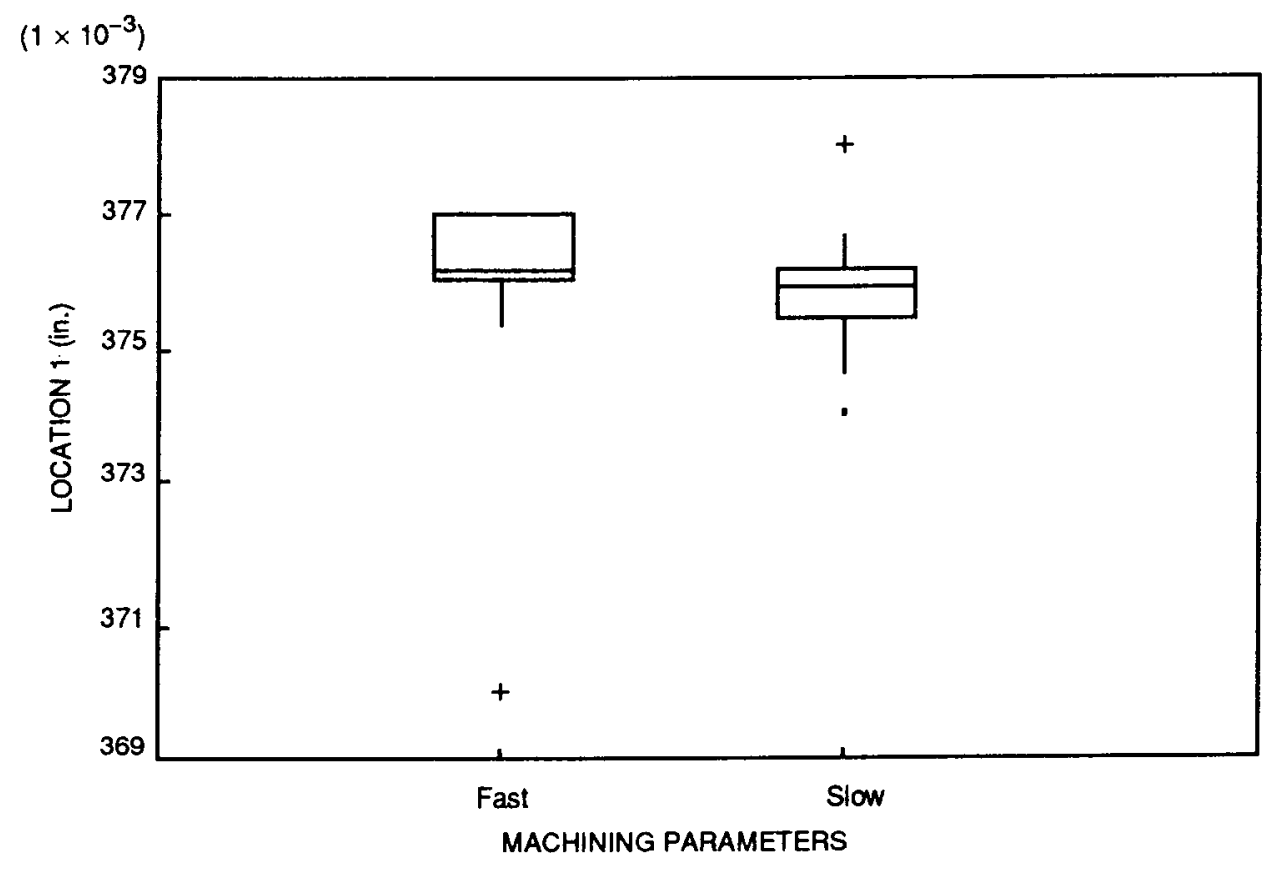

Fast -400 sfpm, 0.0072 ipr $\quad$ Slow -300 sfpm, 0.0032 ipr

FIGURE 25. Stem Diameter Evaluation 
RFP-4552

4 U.S. GOVERAMENT PRINTING OFFICE: 1002-675-076651 16 